\title{
Unorden
}

\section{Ecosystem Services in Forests}

How to assess and value them? Nordic Workshop, Oslo, Thursday 13th September 2012
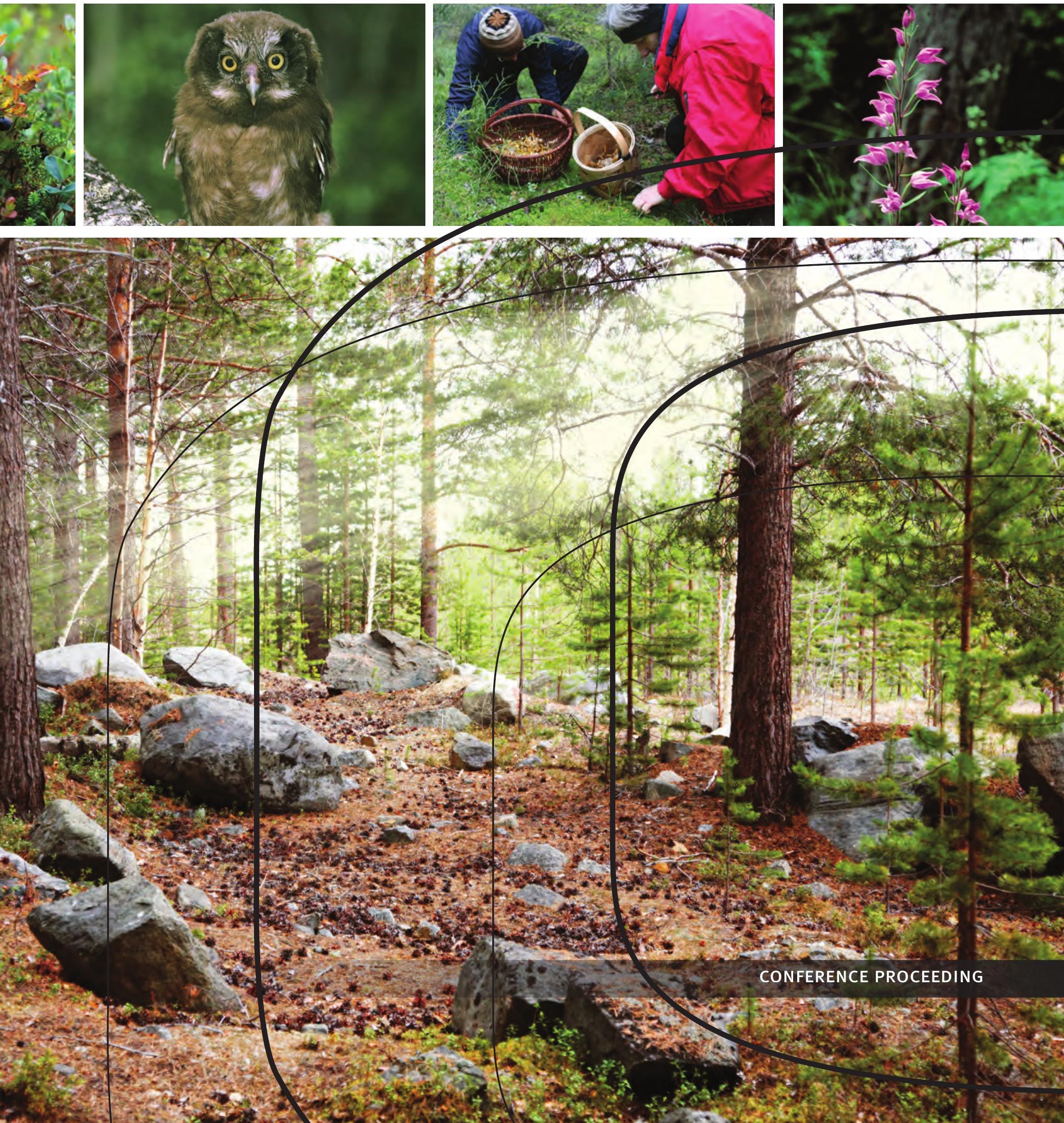

4 norden 



\section{Ecosystem Services in Forests}

How to assess and value them?

Nordic Workshop, Oslo, Thursday 13th September 2012

- Conference report 
Ecosystem Services in Forests

How to assess and value them?

Nordic Workshop, Oslo, Thursday 13th September 2012 - Conference report

ISBN 978-92-893-2785-5

ISBN 978-92-893-2786-2 (EPUB)

http://dx.doi.org/10.6027/TN2014-534

TemaNord 2014:534

ISSN 0908-6692

(C) Nordic Council of Ministers 2014

Layout: Hanne Lebech

Cover photo: Lars Løfaldli; Sissel Rübberdt; Svein T. Båtvik; ImageSelect

This publication has been published with financial support by the Nordic Council of Ministers. However, the contents of this publication do not necessarily reflect the views, policies or recommendations of the Nordic Council of Ministers.

\section{www.norden.org/en/publications}

\section{Nordic co-operation}

Nordic co-operation is one of the world's most extensive forms of regional collaboration, involving Denmark, Finland, Iceland, Norway, Sweden, and the Faroe Islands, Greenland, and Åland.

Nordic co-operation has firm traditions in politics, the economy, and culture. It plays an important role in European and international collaboration, and aims at creating a strong Nordic community in a strong Europe.

Nordic co-operation seeks to safeguard Nordic and regional interests and principles in the global community. Common Nordic values help the region solidify its position as one of the world's most innovative and competitive.

\section{Nordic Council of Ministers}

Ved Stranden 18

DK-1061 Copenhagen K

Phone (+45) 33960200

www.norden.org 


\section{Content}

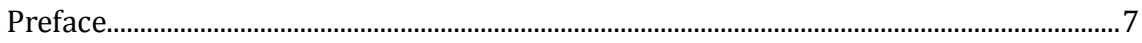

Short summary

Concluding remarks............................................................................................. 10

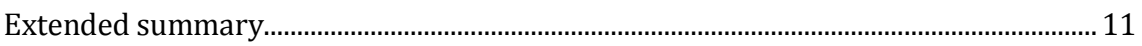

The workshop was organized in four sessions .......................................................... 11

Concluding remarks................................................................................................ 15

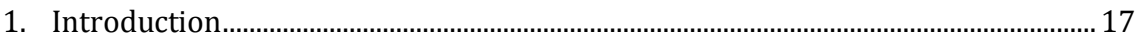

1.1 Workshop Background.................................................................................. 17

2. Session 1 Introductory presentations ................................................................. 21

2.1 Welcome .............................................................................................................. 21

2.2 Setting the scope............................................................................................ 23

2.3 Values of ecosystem services- challenges and opportunities........................ 25

2.4 Policies for sustainable forest management in Europe .................................. 28

3. Session 2 Forest Ecosystem Services....................................................................... 31

3.1 Biodiversity and links to other ecosystem services....................................... 31

3.2 Forest Ecosystem Services - Carbon sequestration....................................... 33

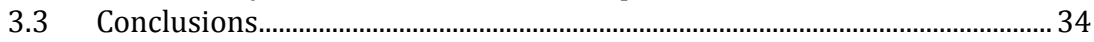

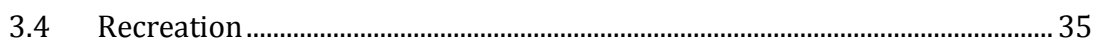

4. Session 3 How to value and incorporate values into decision making? Focus

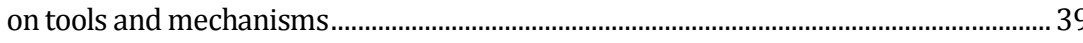

4.1 How information on the value can contribute to sustainable policy

4.2 Experiences from the use of different assessment tools regarding the value of biodiversity and ecosystem services in Denmark ...................... 41

4.3 Non-market values and decision making: Experiences from

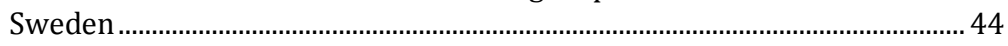

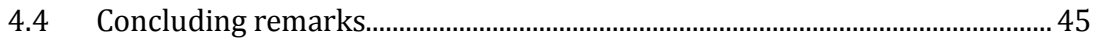

4.5 The potential of participatory multi-criteria analysis in ecosystem

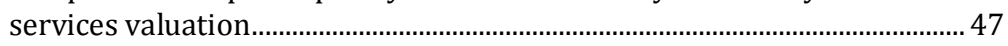

4.6 Forest valuation studies in a Nordic context................................................ 49

4.7 Ecosystem services in forests - Research and research needs....................... 51

5. Session 4: Directions for the future. Recommendations for future work,

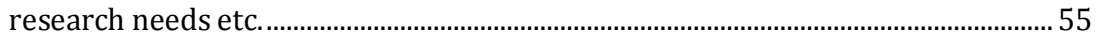

$5.1 \quad$ First discussion: Benefits, values and methodology ............................................ 55

5.2 Second discussion: Knowledge gaps and proposals for Nordic

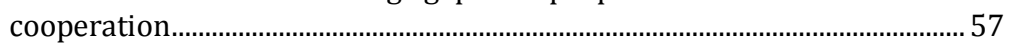

5.3 Concluding words - and further work ....................................................... 59

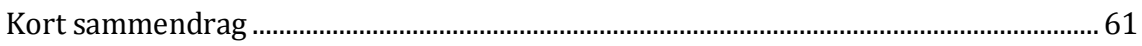

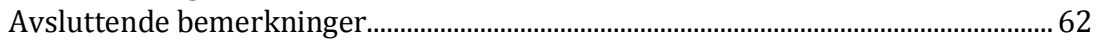

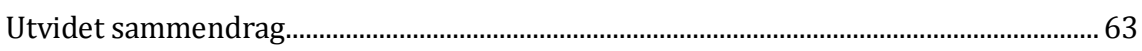

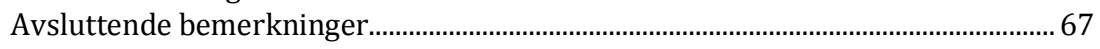

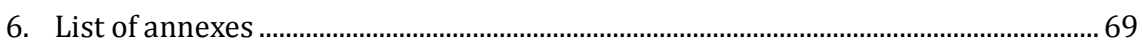




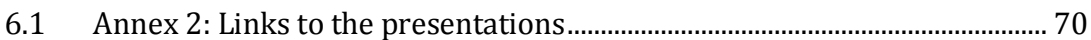

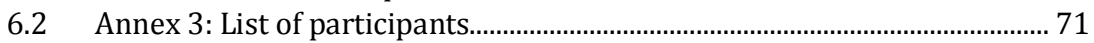

6.3 Annex 4: Relevant reports and websites ......................................................... 72 


\section{Preface}

Ecosystem Services is a generic term for all the services provided by nature, which we depend on for our well-being and quality of life. Well-functioning ecosystems provide us with clean water and air, food and other raw materials, recreation, carbon sequestration and other services that together are essential for our physical and mental well-being. The Nordic countries attach great importance to the findings of the UN study known as the Millennium Ecosystems Assessment, which highlights ecosystem services and the need to maintain ecosystem functions. Approximately $60 \%$ of the ecosystem services examined were degraded or used unsustainably.

People's living conditions are influenced by our ability to live together with the ecosystems and utilize them without destroying them. One of the underlying reasons for the decline of ecosystem services is that their "true" values are not taken into consideration in decision making. Enhancing knowledge about the values associated with biodiversity and ecosystem services in order to improve the basis for decision making is important, as has been illustrated by the international study on the Economics of Ecosystems and Biodiversity (TEEB).

Making sure that society at large is aware of the vital importance of ecosystem services is a significant undertaking. Exchanging knowledge and experiences on how to assess and value ecosystem services in the Nordic countries can create added value with regard to the implementation of the Aichi targets adopted by the Convention on Biological Diversity. This workshop on ecosystem services in forests is one step along this road. Ecosystem services valuation is a novel field, at least in its practical application, and we would like to thank all the participants of the workshop for their valuable contribution.

The workshop was arranged as part of the Norwegian chairmanship of the Nordic Council of Ministers in 2012.

Oslo, 20 September 2013

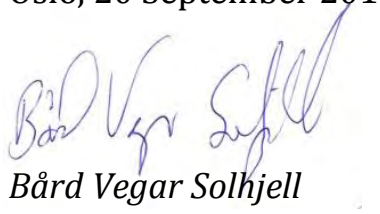

Minister of the Environment, Norway 



\section{Short summary}

A Nordic Workshop on "Ecosystem Services in Forests - how to assess and value them" was held in Oslo Thursday the $13^{\text {th }}$ of September 2012. The workshop was organized as part of the Norwegian chairmanship of the Nordic Council of Ministers in 2012. The objective of the workshop was to exchange knowledge and experiences with different ways to assess and value ecosystem services in forests, with a special focus on non-market goods and services such as biodiversity, climate regulation/carbon sequestration and recreation. Further aims included addressing different approaches and tools to integrate values of the different ecosystem services into decision-making processes in the Nordic countries.

The workshop brought together scientists, policy makers, managers and other stakeholders with an interest in assessment and valuation of ecosystem services in forests. During the day, 13 presentations were made, and altogether 41 participants had the opportunity to discuss the way forward and to formulate issues and research fields as recommendations to the Nordic Council of Ministers. This report presents a synthesis of the presentations and provides a brief summary of issues that were raised in the discussions. The workshop addressed both current knowledge of services as well as challenges and possibilities related to assessment and valuation, and challenged participants to formulate new and important issues based on their respective fields of expertise.

The workshop was organized in four sessions. The first session provided presentations that introduced background information for the workshop, including expectations and policy demands with regards to approaches and tools that assess and value ecosystem services. In the second session three important ecosystem services in the Nordic countries namely biodiversity, carbon sequestration and recreation were presented in more detail. The third session addressed experiences in the Nordic countries with regards to assessment and valuation of ecosystem services and how those values could be incorporated into decision making. The fourth session included a discussion on important issues and propositions for future work and research needs. Based on the information presented at the workshop and the participants' expertise in the field, the participants responded to questions raised by the organizers. 


\section{Concluding remarks}

Our knowledge and understanding of biodiversity and ecosystem services and their values is improving, but there is still a long way to go before the Nordic countries can meet the adopted targets of the Convention on Biological Diversity stating that biodiversity values shall be integrated into national and local development and planning processes, and incorporated into national accounting and reporting systems. There is a need to increase our knowledge of the importance and value of ecosystem services, and how this knowledge can be better integrated into all relevant decision-making processes. This workshop has been one step along the road to improving our understanding. 


\section{Extended summary}

A Nordic Workshop on "Ecosystem Services in Forests - how to assess and value them" was held in Oslo Thursday the $13^{\text {th }}$ of September 2012. The workshop was organized as part of the Norwegian chairmanship of the Nordic Council of Ministers in 2012. The objective of the workshop was to exchange knowledge and experiences with different ways to assess and value ecosystem services in forests, with a special focus on non-market goods and services such as biodiversity, climate regulation/carbon sequestration and recreation. Further aims included addressing different approaches and tools to integrate values of the different ecosystem services into decision-making processes in the Nordic countries.

The workshop brought together scientists, policy makers, managers and other stakeholders with an interest in assessment and valuation of ecosystem services in forests. During the day, 13 presentations were made, and altogether 41 participants had the opportunity to discuss the way forward and to formulate issues and research fields as recommendations to the Nordic Council of Ministers. This report presents a synthesis of the presentations and provides a brief summary of issues that were raised in the discussions. The workshop addressed both current knowledge of services as well as challenges and possibilities related to assessment and valuation, and challenged participants to formulate new and important issues based on their respective fields of expertise.

\section{The workshop was organized in four sessions}

The first session provided presentations that introduced background information for the workshop. There are expectations and policy demands with regards to approaches and tools that assess and value ecosystem services. As a follow up of the UN studies Millennium Ecosystem Assessment (MA) and The Economics of Ecosystems and Biodiversity (TEEB), several high level policy commitments have been made to integrate all the values of biodiversity and ecosystem services into decision-making processes (as is reflected in the adopted targets under the Convention on Biological Diversity). The session also addressed some of the challenges and opportunities associated with valuation (as ecosystem complexity, resili- 
ence and non-linearity, the role of discount rates, uncertainty on valuation methods and people's preferences over time, as well as institutional framework).The concept of ecosystem services can be an eye-opener to understand our dependency on nature. Forests were chosen as a case for the workshop as forest ecosystems are important for human well-being, and forests are important ecosystems in the Nordic countries. Policy challenges involved in Sustainable Forest Management (SFM) were discussed, including the need for a balanced and dynamic understanding of economic, environmental and social values. Critical issues currently in focus for SFM are among others forests and climate change and development of adequate adaptation and mitigation measures, and improvement of biodiversity through increased nature conservation and improved integrated forest management. Sustainable management criteria have been established but need to be further developed.

In the second session three important ecosystem services in the Nordic countries namely biodiversity, carbon sequestration and recreation were presented in more detail.

The natural values in forests are important, as $60 \%$ of all known species live in forests. There are also important ecosystem processes in forests. Different aims for forest management can be balanced in the preservation of different ES in the forests. A key question is how biodiversity composition can be related to ecosystem services. Some links between biodiversity components and ecosystem services are known, but we don't know the relationship for most of the components.

Forests (forest soil and vegetation) play a key role in the global carbon balance and atmospheric $\mathrm{CO}_{2}$-concentration. Without forest carbon sinks the change in climate would be faster with more serious effects on ecosystems and human well-being. The rate of forest carbon sequestration is determined by management. Studies show that it is possible to find win-win solutions with carbon sequestration and other ecosystem services (such as maintenance of biodiversity), and that co-benefits should be systematically analyzed.

Forests are very important for recreation as forests are the most visited type of landscape for (daily) outdoor recreation in most Nordic countries. We have good national survey data in the Nordic countries, but we lack local data about visitation, satisfaction, societal impacts etc.

The third session addressed experiences in the Nordic countries with regards to assessment and valuation of ecosystem services and how those values could be incorporated in decision making.

Some trends in the Nordic countries with regards to assessment and valuation were identified. There is an increasing awareness of the need to 
understand, describe, measure, and value the different ecosystem services. Valuation can contributes to better informed decision making, e.g. by providing information about the economic importance of the services.

The workshop demonstrated that the Nordic countries have some experience in valuation of provisioning services, some with cultural services, and that much less work has been done on regulating and supporting services.

The scientific community experiences increased demand from authorities to value environmental change. There seems to be increasing demand for non-market valuation from funders and stakeholders and greater focus on its relevance for decision making in different ways. There is a greater emphasis on inter-disciplinary research, multiple use considerations and more social science and economics in traditional natural science domains. There is also research that can contribute to decision making/sustainable management, but thus far the indirect influence of valuation on decision making has probably been most important. (There were fewer valuation studies in the past and a fear of "valuing the invaluable" amongst many stakeholders. Today there are many more studies and a greater acceptance for monetary valuation of different environmental services).

With regards to methods, the workshop showed that ecosystem values can be evaluated in different ways. There are different possibilities and limitations on how to value them in relation to data available and methodology. For many ecosystem services there is insufficient knowledge, with others you can give a qualitative review, some you can quantify, and for only a few it will be possible to value in monetary terms. The choice of method depends among other things on the context/circumstances in which they are supposed to find place. (E.g. values as tools for authorities to develop new policies/implementing political decisions, litigation, as one input on its own in decision making, or along with others).

There are different non-market valuation methods such as qualitative, quantitative, monetary (stated preferences methods, revealed preferences methods, cost-based approaches), multi-criteria analysis, participatory approaches and deliberative processes. During the workshop different approaches were presented regarding research and decision support systems (physical accounts, willingness to pay, cost-effective analysis, the InVest model, multi-criteria analysis etc.)

With regard to economic valuation studies in the Nordic countries, the method most frequently used in non-market valuation studies is stated preferences methods and thereafter revealed preferences methods. 
The development of multi-criteria approaches in environmental research is a growing area of innovation. As opposed to monetary valuation, they can handle multiple objectives and incommensurable criteria. They can also be used in participatory processes, where the methods can be helpful in illustrating trade-offs.

Additional issues in need of attention were also raised. The workshop confirmed the need to develop approaches and tools, and to arrive at results useful for decision making/makers, including a more systematic monitoring of environmental values over time e.g. through official statistics.

The need for more integrated research that also includes long term studies at the landscape level was stated, as well as an appraisal of the impact of policies and management decisions and land use change on the value of ES. Awareness of ecological thresholds is important. The fact that people's preferences, behavior and choices may change over time represents a special challenge.

The need for multi-disciplinary approaches and inter-disciplinary cooperation when assessing and valuing ES was mentioned by several presenters, as a multi-disciplinary approach is often necessary for increased policy relevance of non-market valuation research.

Another item mentioned by several of the presenters was the need to address and understand trade-offs, both trade-offs in relation to time and space, those who win and lose, and between services. Who benefits from one service may be considered, but as ecosystems produce a basket of ES and ES are jointly produced, trade-offs is a key issue. Focusing on one ecosystem service in management can adversely affect the production of other ES, and integrated management, integrated research and multiple objectives approaches were called for. Time, geographical scale and target groups are key elements when assessing ES. It was pointed out that management in the past will affect biodiversity in the present (e.g. extinction debt). But as some studies show, it may also be possible to find win-win solutions, as with carbon sequestration and other ecosystem services such as maintenance of biodiversity. It was also illustrated that several silvicultural operations may have positive effects on biodiversity without high costs.

The fourth session included a discussion on important issues and propositions for future work and research needs. Based on the information presented at the workshop and the participant's expertise in the field, the participants responded to questions raised by the organizers.

Several viewpoints on topics/issues, that require attention or need to be solved, were forwarded. Items raised included e.g. synergies and 
trade-offs between different ecosystem services, winners and losers depending on decisions/ distributive issues, information needs in multicriteria analysis and willingness to pay studies, knowledge of biodiversity, the link between biodiversity and ecosystem services, ecosystem complexity and ecological thresholds, valuation of intermediate services and the role and value of soil biodiversity .

In addition, several viewpoints with regard to knowledge gaps and proposals for Nordic cooperation were discussed. The workshop identified more knowledge about biodiversity and the link between biodiversity, ecosystem processes/functions and ecosystem services as important elements for future research. Several participants proposed developing and establishing common indicators of ecosystem services through Nordic cooperation. This could also contribute to the further development of additional criteria and indicators for Sustainable Forest Management.

Methods for analyzing synergies and trade-offs between services, and distributive issues with regard to who will benefit and lose depending on the decision, were also proposed as future topics for Nordic cooperation. Green national accounting was further considered in need of further work within a Nordic framework. Preservation of soil carbon pools and sustainable management issues were also among the proposed issues.

\section{Concluding remarks}

Our knowledge and understanding of biodiversity and ecosystem services and their values is improving, but there is still a long way to go before for the Nordic countries can meet the adopted target of the Convention on Biological Diversity, stating that biodiversity values shall be integrated into national and local development and planning processes, and incorporated into national accounting and reporting systems. There is a need to increase our knowledge of the importance and value of ecosystem services, and how this knowledge can be better integrated into all relevant decision-making processes. This workshop has been one step along the road to improving our understanding. 



\section{Introduction}

As part of the Norwegian chairmanship of the Nordic Council of Ministers in 2012, the Norwegian Ministry of the Environment initiated a Workshop on Ecosystem Services in Forests, since assessment and valuation of ecosystem services is important for the Nordic countries, and Nordic cooperation can create added value with regard to the implementation of the Aichi targets adopted by the Convention on Biological Diversity.

Thursday 13th September, 2012, a one day workshop was organized in Oslo by the Ministry of Environment and the Directorate for Nature Management, ${ }^{1}$ on behalf of the Nordic Council of Ministers Working Group on Terrestrial Ecosystems (acting for the Committee of Nordic Senior Officials on Environmental Affairs).

The workshop brought together scientists, policy makers, managers and others stakeholders with an interest in assessment and valuation of ecosystem services in forests. During the day, 13 presentations were made, and altogether 41 participants had the possibility to discuss the way forward and to formulate issues and research fields as recommendations to the Nordic Council of Ministers. This report presents a synthesis of the presentations and the outcome of the workshop. The workshop consisted partly of presentations that addressed current knowledge of services and challenges and possibilities related to assessment and valuation, and partly an effort by the participants to formulate new and important issues based on their respective fields of expertise.

The report was compiled by Hilde Kyrkjebø, the Norwegian Directorate for Nature Management (the Norwegian Environmental Agency from July 2013). The presentations from the workshop can be downloaded from the Norwegian Environmental Agency's homepage.

\subsection{Workshop Background}

The UN's Millennium Ecosystem Assessment highlighted the need to maintain ecosystem functions to secure ecosystem services. Ecosystem services have become an important concept for linking the functioning 
of ecosystems to human welfare. The valuation of ecosystem services has gained much attention lately, among others through the TEEB project (The Economics of Ecosystem and Biodiversity) that has enhanced the knowledge and awareness of these values. These initiatives are followed up in the Strategic Plan under the Convention on Biodiversity (incl. Aichi targets).

"Ecosystem services" is a generic term for all the services provided by nature, which we depend on for our well-being and quality of life. Ecosystem services include both traditional goods provided by nature (food, fiber, fuel), which have market prices, and public goods that normally are not traded in markets (such as climate regulation, water protection and biodiversity). This economical invisibility and the use of inappropriate policy incentives can mean that there is a risk that we will overexploit ecosystems without being aware of what we are losing.

Identifying and assessing ecosystem services and the links to our well-being and the quality of life is pioneering work. Exchanging experience in the Nordic countries on how to assess and value ecosystem services is important for improved understanding of the value of ecosystem services and for policy making. The workshop was initiated as a contribution to a Nordic follow up of the ambitions addressed in TEEB.

Forests were chosen as a case for the workshop as forest ecosystems are important for human well-being, and forests are important ecosystems in the Nordic countries.

Forest ecosystems provide many benefits to society, e.g. trees for timber, fibre and fuel, genetic resources, berries, habitat for wild animals, soil and water protection, carbon sequestration, biodiversity, and recreation. The workshop focused on the non-market elements of these services.

The workshop was arranged to explore different use of the concept of ecosystem services in a Nordic setting, and approaches, tools and methodologies relevant for forests ecosystem. There are different nonmarket valuation methods. Broadly speaking, available method, that can be implemented to assess and value non-market goods and services, can be divided into two groups. In one group we have methods that are founded on economic principles of valuation. These methods, which include stated and revealed preference valuation techniques and cost based approaches, focus on monetary valuation of ecosystem services. Methods in the other group cover a broader spectrum of approaches to ecosystem values, and include qualitative and quantitative aspects of ecosystem services, use of multi-criteria analysis, participatory approaches and deliberative processes to assess values and trade-offs. 
(Though the latter types of approaches can also include considerations of what we think of as traditional economic values).

It is considered important to exchange experiences in the Nordic countries on how to assess and value those services (both through qualitative, quantitative and monetary and other approaches), in order to provide insight, guidance and advice for further work on the issue. It is also important to exchange experience on how to value and incorporate values into decision making (e.g. by the use of different tools and mechanisms to address inter-linkages, synergies and conflicts of interest between different ecosystem services and beneficiaries of the services).

\section{The aim of the workshop}

- To address and discuss different ways to assess and value ecosystem services in forests, with a special focus on non-marketed elements such as biodiversity, climate regulation/carbon sequestration and recreation.

- To address different approaches and tools for integrating values of the different ecosystem services into the decision-making processes in the Nordic countries.

- To bring together natural scientists, economists, social scientists and people working with environmental policy making and management to discuss the way forward, and to discuss different ways of assessing and valuing ecosystem services.

\section{Report outline}

- Summary.

- Introduction.

- Session 1 Introductory presentations.

- Session 2 Forest Ecosystem Services, presentation of three important ecosystem services in the Nordic countries namely biodiversity, carbon sequestration and recreation.

- Session 3 How to value, and how to incorporate values into decision making, presentation of experiences from valuation in the Nordic countries.

- Session 4 Directions for the future, discussion and proposals for future work.

- The report is supplemented with appendices that include the workshop programme, links to the presentations, a list of participants and links to relevant reports and websites. 



\section{Session 1 Introductory presentations}

Session 1 included introductory presentations, and the speakers in this session discussed development and ongoing work regarding ecosystem services, challenges and opportunities regarding valuation of ecosystem services, and policies for sustainable forest management in Europe.

\subsection{Welcome}

Henriette Westhrin, State Secretary, Norwegian Ministry of Environment, opened the workshop and welcomed the participants to Oslo. She referred to the forest around the city of Oslo as one good example of a forest area that has been protected against further building activities, precisely due to the great value it represents to the citizens of Oslo (markaloven). ${ }^{2}$ There is great support among the citizens of Oslo regarding this protection of the forest. One question that could be asked is whether it's also good economics, and she asked if it is possible to set a price on recreation as such.

Ecosystem services that represent traditional goods from nature (food, fiber and fuel), and that have a market value, are easy to assess. It is more complicated with for example biological diversity and recreational values. In addition, the linkage between biological diversity and the production of goods and services is often not sufficiently known. Perhaps we make decisions today that we think are wise economically, but which actually are the opposite, because the cost to our economy and our welfare related to the loss or degradation of such services do not show up in the accounts (for the companies and in the national accounts).

These are questions that are regarded as important in the Norwegian chairmanship. To follow up of the TEEB-study is also considered to be important, as the study shows how important it is to take all the val-

2 Markaloven- a law which has the intention to encourage and accommodate outdoor recreation, aesthetical experiences of nature and sports. Forestry can be continued, but building activities are prohibited. 
ues that natural ecosystems deliver (also those that are not traded in markets) into account in all relevant decision-making processes (both in the public and the private sector).

Referring also to her experiences as a state secretary in the Ministry of Finance, Westhrin emphasized how important it is to have a good link between environmental and economic policy. That's why Norway has introduced indicators on sustainable development in the national budget as supplementary information. Recently a nature-index for Norway has been developed showing the state for the different ecosystems. Information from the nature-index are now included in the indicators on sustainable development in the national budget. But there is still a long way to go before we can say that we have included the ecosystem services in decision making as such. That is why we have commissioned an expert commission that will study the values of ecosystem services in Norway. Because of the strong connection between economy and ecology, the Ministry for Finance is coordinating work related to sustainable development.

She pointed out that the Convention on Biological Diversity has adopted new biodiversity targets. A short version of the new target for 2020 is "Take effective and urgent action to halt the loss of biodiversity in order to ensure that by 2020 ecosystems are resilient and continue to provide essential services, thereby securing the planet's variety of life, and contributing to human well-being." Is has also been adopted that by 2020 at the latest, biodiversity values have been integrated into national and local development and planning processes and are being incorporated into national accounting and reporting systems. The whole world is now working to implement those decisions. The Nordic Council of Ministers has incorporated the decisions into the aims for the Nordic cooperation, and it will have an important place in the Environmental Action Plan 2013-2018.

In the Nordic countries forests are important both for the production of timber and energy, and it is also very important for biodiversity. For instance half of the threatened and near threatened species in Norway are connected to the forests. Forests are also important in many ways with regard to climate change, and not least they are important for recreation. Since there are so many values and interests connected to the forest, policy issues are frequently discussed. Westhrin highlighted that there are diverging views and debate within the scientific community as well. This is one reason why she regarded the workshop as very important. 


\subsection{Setting the scope}

Hilde Kyrkjebø, Norwegian Directorate for Nature Management, ${ }^{3}$ gave an introductory talk about the aim of the workshop and presented background and international initiatives that has put ecosystem services on the agenda.

The Millennium Ecosystem Assessment (MA 2005) assessed the consequences of ecosystem change for human well-being, and established a scientific basis for action needed to enhance the conservation and sustainable use of ecosystems and their contribution to human well-being. MA viewed ecosystem and hence biodiversity in terms of benefits (ecosystem services) delivered to society, and through MA ecosystem services (ES) "the benefits people obtain from ecosystems" were introduced on the global agenda. MA defined four main categories of services: provisioning (e.g. food, freshwater, wood and fiber); regulating (e.g. climate regulation, flood and disease regulation, water purification); cultural (e.g. aesthetic, spiritual, educational, recreational); and supporting (e.g. nutrient cycling, soil formation, primary production). According to MA biodiversity is underpinning all the services.

While we pay for some ecosystem services like food and fiber, we are often unaware of the importance of others such as water or air purification. Such values are often overlooked or poorly understood, and this may lead to inadequately informed decisions on how to use these resources, which may lead to overexploited ecosystems. One of the recommendations from MA was to increase the information on non-market values from ecosystem services, and to incorporate those values in resource management and decisions.

To address this, a major international undertaking called The Economics of Ecosystems and Biodiversity (TEEB) was initiated by the Environment Ministers of G8+5 countries in 2007. The objective of TEEB was to draw attention to the global economic benefits from ecosystems and to highlight the growing costs of biodiversity loss and ecosystem degradation. TEEB aims to demonstrate that biodiversity, ecosystems and their services have multiple values - to economy, society, businesses and individuals, and to show/help to integrate these values into everyday decisions. TEEB offers an overview of different policy options as a response to the growing evidence of the impact of ongoing loss of biodiversity and ecosystem services. 4

\footnotetext{
${ }^{3}$ The Norwegian Environmental Agency from July 2013.

${ }^{4}$ TEEB is coordinated by the United Nations Environment Programme (UNEP).
} 
Kyrkjebø pointed out that since the launch of the TEEB in 2010 several high level policy commitments have been made to integrate the value of biodiversity and ecosystem services into decision-making processes. The new Strategic Plan for Biodiversity 2011-2020 to implement the UN Convention on Biological Diversity (CBD), adopted at the tenth meeting of the Parties in October 2010 (Nagoya, Japan), outlines the following target "Take effective and urgent action to halt the loss of biodiversity in order to ensure that by 2020 ecosystem and their services are resilient and continue to provide essential services... "and also that "By 2020, at the latest, biodiversity values have been integrated into national and local development and poverty reduction strategies and planning processes and are being incorporated into national accounting, as appropriate, and reporting systems." Ecosystem services are also explicit in EU policy, and the EU Biodiversity Strategy to 2020 launched in May 2011 echoes the same message. 5

She also referred to different development arenas regarding ES as the Intergovernmental Platform on Biodiversity \& Ecosystem Services (IPBES) for science-policy interface, and to activities within the research and development community. She also mentioned other relevant work on ecosystem services such as the UK National Ecosystem Assessment (UK NEA 2011) that provides a comprehensive overview of the state of the natural environment in the UK, and to other national ecosystem assessments. Further, TEEB is producing thematic reports as e.g. TEEB for Cities, TEEB for water and wetlands, and a TEEB paper on natural capital \& green economy. The United Nations Statistical Division (UNSD) has ongoing work on experimental ecosystem accounts, the World Bank has work on natural capital accounting (WAVES), EEA are involved in e.g. ecosystem classification, and the EU has established a working group on Mapping and Assessment of Ecosystem and their services (MAES). She further referred to relevant activities by the Nordic Council of Ministers, and among these a scoping assessment on the status and value of ecosystem services in the Nordic Countries (Kettunen et al. 2012).

Finally, she summarized that there are expectations and policy demands with regards to approaches and tools to integrate values into decision making. She concluded by presenting the aim of the workshop: to

\footnotetext{
${ }^{5}$ By 2050, European Union biodiversity and the ecosystem services it provides - its natural capital - are protected, valued and appropriately restored for biodiversity's intrinsic value and for their essential contribution to human wellbeing and economic prosperity, and so that catastrophic changes caused by the loss of biodiversity are avoided... By 2020, Halt the loss of biodiversity and ecosystem services in the EU and restore them insofar as feasible, and step up the EU's contribution to averting global biodiversity loss.
} 
address and discuss different ways to assess and value ecosystem services in forests; and to address different approaches and tools for integrating values of the different ecosystem services into decision making processes.

\subsubsection{References}

Kettunen, M., Vihervaara, P., Kinnunen, S., D’Amato, D., Badura, T., Argimon, M. and ten Brink, P. (2012) Socio-economic importance of ecosystem services in the Nordic Countries - Synthesis in the context of The Economics of Ecosystems and Biodiversity (TEEB). Nordic Council of Ministers, Copenhagen.

Intergovernmental Platform on Biodiversity and Ecosystem Services (IPBES):

http://www.ipbes.net/

MA 2005. Millennium Ecosystem Assessment (2005) Ecosystems and Human WellBeing: Synthesis http://www.unep.org/maweb/en/Index.aspx

Strategic Plan for Biodiversity 2011-2020 (2010), Convention on Biological Diversity: http://www.cbd.int/sp/

The Economics of Ecosystems and Biodiversity http://www.teebweb.org/

The EU Biodiversity Strategy to 2020:

http://ec.europa.eu/environment/nature/info/pubs/docs/brochures/2020\%20Bio d\%20brochure\%20final\%20lowres.pdf

The UK National Ecosystem Assessment (UK NEA 2011) http://uknea.unepwcmc.org/

United Nations Statistical Division: http://unstats.un.org/unsd/envaccounting/ seearev/

WAWES http://www.wavespartnership.org/waves/

\subsection{Values of ecosystem services- challenges and opportunities}

Dag Hessen, University of Oslo, and a member of the Norwegian government's expert commission on the values of ecosystem services. He was invited to present the work of the commission and to present some views on the challenges and opportunities related to valuation of ecosystem services.

Hessen started by referring to the new Norwegian Act on Biodiversity where ecosystem functioning and ecosystem services are important aspects. He discussed different reasons for why it is important to conserve biological diversity 1) The intrinsic value of nature, 2) experiences in and from nature, e.g. aesthetic or recreational values (both biocentric and anthropocentric), and 3) as a basis for life and foundation of welfare and economic activity. Hessen stated that one should start with the in- 
trinsic value and ethical considerations and to use economic value as an additional argument.

We do not understand our dependency on nature, and the concept of ecosystem services can be an eye opener to understand this dependency. One example is the importance of wild bees for pollination of coffee. Another is the use of fungi in biotechnology and medicine. He stated that we should provide more of these examples. The forest is an important ecosystem for Norway providing many ecosystem services.

He presented the Norwegian expert commission on the values of ecosystem services initiated in 2011 that will present a public report (NOU) to the government by 31 August 2013. He hopes that the report will lead to a white paper.

The commission has a broad mandate, covering many aspects of Norwegian ecosystem and ecosystem services:

- Consider and extract if and how key terms and approaches from the TEEB study can be used in Norway.

- Collect, consider and present knowledge on the values that biodiversity and ecosystem services constitute for Norway today and for future generations.

- Explore how knowledge on the values of biodiversity and ecosystem services can be strengthened.

- Propose methods for assessing and valuing consequences for welfare and quality of life resulting from changes in biodiversity and ecosystem services.

- Consider how such values can be estimated or valued as part of Norway's national wealth.

Valuation elements are also described in the mandate:

- "The committee will review different ways of measuring and demonstrating the values related to ecosystem services, and assess the advantages and disadvantages of and the potential for valuation in monetary terms."

- "The committee will identify needs for better statistics and indicators relating to ecosystem services in Norway."

- "The committee will review and evaluate different valuation methods and measurement tools, and make recommendations on their use in Norway." 
Ways to manage trade-offs will be addressed, both trade-offs in relation to time, space, those who wins and loose, and between services.

Hessen mentioned some of the challenges involved in valuation of ecosystem services:

- Capturing how different users see different values.

- People's behaviour and choices.

- Institutional framework, users and target groups.

- Legitimacy, costs, stakeholder involvement etc..

- Risk and uncertainty.

- People's preferences over time (preference uncertainty).

- Future ecosystem service production (supply uncertainty).

- Uncertainty in valuation methods.

- Ecosystem complexity, resilience and non-linearity.

- Role of discount rates.

He particularly emphasized that discount rates are very important as this is related to how ecosystem services are valued in the future.

There is a need to understand, describe, measure, and value the different ecosystem services. There will be different possibilities and limitations on how to value them in relation to data available and methodology. He presented a figure showing the different approaches to assessing and valuing different ecosystem services. For many ecosystem services you lack knowledge, with others you can give a qualitative review, some you can quantify, and for only a few it will be possible to value in monetary terms.

\subsubsection{More information}

Ministry of the Environment home page for the expert commission on values of ecosystem services: www.regjeringen.no/okosystemtjenester 


\subsection{Policies for sustainable forest management in Europe}

Knut Øistad, Norwegian Ministry of Agriculture and Food, presented European forests policy as adopted by Forest Europe, and also an overview of the state of Europe's forests with reference to the State of Europe's Forests 2011 Report.

The State of Europe's Forests 2011 Report provides a comprehensive, up-to-date description of the status and trends of forests and forest management in Europe. The majority of Europe's forests area (80\%) is located in the Russian Federation, and Europe is a forest-rich region with forest covering $45 \%$ of the land area. Europe (including the Russian Federation) constitutes 1.02 billion hectares of forest, which amounts to $25 \%$ of the world total. Forest area continues to increase as fellings are below increment in most countries. European forests sequester increasing amounts of carbon in tree biomass.

Most forests in Europe have a management plan, and forest management practices increasingly promote the conservation and sustainable use of biodiversity. The area of protected forests is expanding in Europe, and there is also a growing awareness of the importance of forest management for protection of water, soil and infrastructure.

Critical issues currently in focus are:

- Forests and climate change, and development of adequate adaptation and mitigation measures.

- Increased use and mobilization of wood resources, particularly with respect to renewable energy targets.

- Improvement of biodiversity through increased nature conservation and improved integrated forest management.

- Promotion and improved marketing of non-wood goods and forest ecosystem services, such as protective functions, biodiversity and land integrity.

- Economic viability of forest sector and its contribution to rural development and a green economy.

The challenges and needs concerning the forests are common and transboundary in all of Europe, and cooperation is needed. Forest Europe (The Ministerial Conference on the Protection of Forests in Europe MCPFE) is a Pan-European political process for the sustainable management of the forests. A common understanding of what sustainable 
forest management encompasses has been the basis of the collaboration. The member countries have agreed on a joint definition of sustainable forest management:

\footnotetext{
"The stewardship and use of forests and forest lands in a way, and at a rate, that maintains their biodiversity, productivity, regeneration capacity, vitality and their potential to fulfil, now and in the future, relevant ecological, economic and social functions, at local, national, and global levels, and that does not cause damage to other ecosystems."
}

Forest Europe has developed this common understanding among its 46 member countries (48 countries and organizations are observers), and has also developed policy guidelines, criteria and indicators for sustainable forest management.

Forest Europe has developed and adopted the following 6 panEuropean criteria for sustainable forest management: Maintain and enhancement of; 1.Forest resources and contribution to the global carbon cycle; 2 .Health and vitality; 3 . Productive functions; 4 . Biological diversity; 5.Protective functions; and 6.Socio-economic functions. These criteria and their associated indicators (35 quantitative and 17 qualitative) are used for reporting, and will be evaluated in the near future. They have been developed through a participatory process, including contributions by the scientific community, stakeholders and policy makers.

Øistad concluded by discussing some of the policy challenges involved in Sustainable Forest Management (SFM). SFM is about people more than trees, and since people change their minds, SFM is a moving target. SFM is about finding the right balance between a dynamic understanding of economic, environment and social values. Since forests, environment and economic development has a different time horizon, this represents a particular challenge.

\subsubsection{References}

FOREST EUROPE, UNECE and FAO 2011: State of Europe's Forest 2011.Status and Trends in Sustainable Forest Management in Europe http://www.foresteurope.org/ state-europes-forests-2011-report.

More information:

Forest Europe: www.foresteurope.org. 



\section{Session 2 Forest Ecosystem Services}

In session 2, three important ecosystem services in the Nordic Countries were presented, namely biodiversity, carbon sequestration and recreation.

\subsection{Biodiversity and links to other ecosystem services}

Erik Framstad, Norwegian Institute for Nature Research (NINA) talked about biodiversity and links to other ecosystem services (ES), and a main topic was how different aims for forest management can be balanced in the preservation of different ES in the forests.

First Framstad emphasized the variation and dynamics that characterize Nordic forests. They are established after the last ice age, have characteristic ecological patterns and processes, and old trees and dead wood offer varied habitats. Nordic forests cover a large area and represent a large amount of biomass, Sweden and Finland having the largest growing stocks of 3.3 and 2.3 million $\mathrm{m} 3$ respectively. He also pointed to differences in the forest types and age composition between the Nordic countries. Important human influence on forests today is forest harvesting (removal of biomass, coarse dead wood and old trees, and through creation of new landscape patterns), climate change, nitrogen deposition and unbalanced species communities.

Different aims of forest management mean potential for synergies and conflicts between e.g. natural values (like biodiversity, landscape and recreation), climate system component (carbon stocks) and economic values (like biomass and tourism). Framstad stressed the importance of the natural values in forest, with special attention paid to important ecosystem processes and to biodiversity as $60 \%$ of all known species are in forests.

Biodiversity can be divided into structural, compositional and functional biodiversity (Noss 1990). When measuring biodiversity, we mostly measure structure and composition, not the functional biodiversity which is more clearly related to ES. For conservation purposes threatened species, species rich forest types, variation and intactness are of greatest in- 
terest, while components like primary production, decomposition, biogeochemical cycles, trophic interactions and regulatory mechanisms are the most important for maintaining robust ecosystem functions.

Key environmental qualities for biodiversity conservation are e.g. special environmental conditions, old forests, fire refugia, large/old trees, temperate deciduous trees, dead wood and forest fires. Habitats with such qualities should be the main aim for forest conservation. Biodiversity (represented by e.g. particular species, functions, ecosystem structure, functional groups) is the basis for all ecosystem services (like timber, recreation, primary production, climate regulation) (MEA 2005). A key question is how biodiversity composition can be related to ES. Framstad discussed if more ecosystems with more species will give greater diversity of ecological function types, greater biological production, more robust ecosystems and more and better ecosystem services. Production of most ecosystem services depends on more than one/few biodiversity components. Some links between biodiversity components and ecosystem services are known, but we don't know the relationship for most of the components.

High species richness does not always increase ES, and this was illustrated by a study of links between global species richness and carbon in biomass (Strassburg et al. 2010). For Norway, however, high occurrence of red listed species in the south east of Norway (Kålås et al. 2010) corresponds with high forest biomass in this region (Larsson \& Hylen 2007).

In a recent case study based on data from the Norwegian Forest Inventory (NFI), Framstad et al. (2011) analyzed the co-variation between biodiversity and carbon stocks and identified forest types with potential conflict with forestry. Results suggest a close relationship between biodiversity value and annual $\mathrm{CO}_{2}$-uptake, and indicate that old forest conservation benefits both biodiversity and carbon stocks. Potential conflicts with forestry are greatest for rich and old coniferous forests compared to the other NFI forest units (e.g. deciduous forests), but overall the conflicts with forestry appear less than assumed. Framstad discussed natural forest dynamics as a robust management regime. He finally referred to recent studies that show that old growth forests continue to sequester carbon longer than previously assumed, stating the importance of these old forests in carbon sequestration (Framstad et al. 2013). 


\subsubsection{References}

Framstad, E., Stokland, J.N. \& Hylen, G. 2011. Forest protection as a climate measure. Valuable forest types for biodiversity and carbon storage. NINA Report 752.

Framstad, E. (ed.), de Wit, H., Mäkipää, R., Larjavaara, M., Vesterdal, L. \& Karltun, E. 2013. Biodiversity, carbon storage and dynamics of old northern forests. TemaNord 507: 130 pp. Nordic Council of Ministers, Copenhagen.

Kålås, J.A., Viken, Å., Henriksen, S. and Skjelseth, S. (eds.). 2010. The 2010 Norwegian Red List for Species. Norwegian Biodiversity Information Centre/Artsdatabanken, Norway.

Larsson, J.Y. \& Hylen, G. 2007. Skogen i Norge. Statistikk over skogforhold og skogressurser i Norge registrert i perioden 2000-2004. Viten fra Skog og landskap $1 / 07$.

Noss, R.F. 1990. Indicators for monitoring biodiversity: a hierarchical approach, Conservation Biology 4: 355-364.

Millennium Ecosystem Assessment (2005) Ecosystems and Human Well-Being: Synthesis.

Strassburg, B.N. et al. 2010. Global congruence of carbon storage and biodiversity in terrestrial ecosystems. Conservation Letters 3. 98-105.

\subsection{Forest Ecosystem Services - Carbon sequestration}

Raisa Mäkipää, Finnish Forest Research Institute, talked about the importance of forest soil and vegetation on global carbon balance and atmospheric $\mathrm{CO}_{2}$, carbon monitoring, effects of forest management on carbon balance, and carbon sequestration in the future. From the organizers she was particularly asked to address what scientists agree upon and what they debate within this topic.

Mäkipää referred to the global mean temperature increase of $+0.78 \mathrm{C}$ in 70 years (IPCC 4AR 2006) resulting from increased $\mathrm{CO}_{2}$ concentrations, and the increasing role of anthropogenic forcing in recent years to explain this. The importance of forests in the global carbon balance was emphasized (www.globalcarbonproject.org). The global amount of carbon in vegetation, soils and atmosphere were 600,1600 and $750 \mathrm{Gt} \mathrm{C}$ ( $\mathrm{Gt} \mathrm{C}=10^{15} \mathrm{~g}$ of carbon) respectively, and changes in either vegetation or soils lead to changes in the atmosphere.

We do not really know how a changing climate will influence the Nordic forests in the future. In general, increase in biomass production is expected due to climate change, but the response of Norway spruce is debated. Some researchers predict a decline for Norway spruce, which will be substituted by birch, while others do not predict any decline for Norway spruce. An accelerated rate of decomposition is also expected. If forest carbon sink will be maintained or we will see a release of carbon, depends on the net result of increasing biomass compared to accelerated 
decomposition. Mäkipäa assumed that most forests will be a carbon sink also in the future. Forest carbon balance is more affected by management than by climate, and she questioned if different management practices (e.g. whole tree harvest for bioenergy) will be sustainable in the future.

Mäkipää documented her presentation with results from Finnish studies showing that forests in Finland have been carbon sink until now (Liski et al.2006, Monni et al. 2003, Sievänen et al. 2012). Based on reporting the use of forests in climate policy to the Climate Convention, Swedish forests are expected to be greater carbon sinks compared to the Finnish forests (Lehtonen 2012). The dynamic character of the carbon sinks was underlined, and illustrated by a stand scale study where a forest stand was shown to be a carbon source for the first 20 years after clear-felling, and a carbon sink after that (Mäkipää 2011). Several studies were shown illustrating how carbon stocks were affected by e.g. tree species composition, length of rotation period, whole tree harvesting contra conventional harvesting etc. Different management practices were shown to decrease forest carbon sequestration (as whole tree harvest). Management measures to increase carbon sequestration in forests were discussed. Mäkipää concluded that it would be easy to find winwin solutions with respect to carbon sequestration and other ecosystem services, e.g. biodiversity.

\subsection{Conclusions}

- Anthropogenic $\mathrm{CO}_{2}$ emissions are changing the climate.

- Without forest carbon sinks the change in climate would be faster with more serious effects on ecosystems and human well being.

- In the changing climate, biomass production and consequently litter input to forest soil will increase more than rate of decomposition. Thus boreal upland forests may be carbon sinks also in the changing climate if management "allows."

- Rate of forest carbon sequestration is determined by management.

- Forest carbon sink is decreased e.g. by: change in the age class distribution; increased proportion of young stands; whole tree harvesting (branches, tops, stump-root system for bioenergy); increased proportion of deciduous species; and intensive thinnings and avoidance of natural mortality.

- Forest carbon sequestration can be increased e.g. with longer rotation periods, less intensive thinnings (increased natural 
mortality), conservation of old forest (accumulation of dead wood carbon pool there).

- It is easy to find win-win solutions with carbon sequestration and other ecosystem services (such as maintenance of biodiversity). Cobenefits should be systematically analyzed.

\subsubsection{References}

Global carbon project: www.globalcarbonproject.org IPCC 4AR 2006. IPCC WG1 Fourth Assessment Report 2006.

Liski, J., Pussinen, A., Pingoud, K., Mäkipää, R. \& Karajalainen, T. (2001): Which rotation.

length is favourable to mitigation of climate change? Canadian Journal of Forest Research 31: 2004-2013.

Liski, J., Lehtonen, A., Palosuo, T., Peltoniemi, M., Eggers, T., Muukkonen, P. \& Mäkipää, R. (2006): Carbon accumulation in Finland's forests 1922-2004 - an estimate obtained by combination of forest inventory data with modelling of biomass, litter and soil. Annals of Forest Science 63: 687-697.

Mäkipää, R., Linkosalo, T., Niinimäki, S., Komarov, A., Bykhovets, S., Tahvonen, O. \& Mäkelä, A. (2011): How forest management and climate change affect the carbon sequestration of a Norway spruce stand. Journal of Forest Planning 16: 107-120.

Mäkipää, R., Linkosalo, T., Komarov, A. \& Mäkelä, A. 2013. Is mitigation of climate change with biomass harvesting sustainable in Norway spruce stands? Manuscript.

Metla/GHG Inventory/Lehtonen 2012.

Monni, S., Korhonen, R. \& Savolainen, I. 2003. Radiative Forcing Due to Anthropogenic Greenhouse Gas Emissions from Finland: Methods for Estimating Forcing of a Country or an Activity. Env. Management 31: 401-411.

NIR Finland 2011. Finland's National Inventory Report under the UNFCCC.

Sievänen, R. et al. 2013. Carbon stock changes of forest land in Finland under different levels of wood use and climate change. Ann. For. Sci. DOI 10.1007/s13595-0130295-7

\subsection{Recreation}

Odd Inge Vistad, Norwegian Institute for Nature Research, emphasized that there is a long history of human and social science concerning human well-being, outdoor recreation and the value of forests and other types of «ecosystems». He stated that we have to acknowledge this scientific history when implementing e.g. recreation in the ecosystem services frame.

Forests are very important for human well-being, and the forest is the most visited type of landscape for (daily) outdoor recreation in most Nordic countries. 
Research has documented important benefits for individuals and for society regarding outdoor (e.g. forest) recreation. Examples of such benefits are relaxation, stress reduction, physical and mental restoration, health improvements/maintenance, nature experience, nature learning, physical fitness, social contact, mastering life skills, a sense of belonging, local identity, etc. International literature is potentially relevant, but historical, cultural, geographical and social variation is of course important (see references).

Also presented were some basic premises for recreation - such as individual and political interests, access to and presence of forests, as well as the quality of forest (influenced e.g. by forestry practice). Documented facts about local recreational interests and documentation of individual and societal benefits from recreation are important.

He further pointed out some challenges and needs regarding forest recreation:

- Forests are potential development areas.

- Outdoor recreation is a weak societal interest.

- Public Access Right cannot stop building and development activity.

- Public Access Right create a sense of false security (is a "pillow").

- Outdoor recreation is a vulnerable interest in land use planning, and when powerful land use interests come into play

He pointed out that we have very little documented knowledge on the social situation in forests, recreational or protected areas in the Nordic countries (with the exception of Denmark and partly Finland). We have good national survey data in the Nordic countries, but we lack local data about visitation, satisfaction, societal impacts etc. He referred to a statement that Any phenomenon that is not measured and reported does not exist politically.

He stated that we have more useful research than relevant local documentation/useful monitoring data concerning outdoor recreation in forests and the societal impacts. He emphasized the need to identify good and measurable indicators and to implement more social monitoring. In addition to indicators on forest production/forest health and indicators on biodiversity, we also need social indicators. He pointed out some challenges in developing such indicators:

- To identify good and measurable social indicators.

- A good indicator is simplification of complexity. 
- Scale.

- Specific needs in urban forests.

- Other needs for international comparison.

He referred to the Pan-European Indicators for Sustainable Forestry Management through MCPFE (Ministerial Conference on the Protection of Forests in Europe) where there are two relevant indicators today, but he went on to ask if there could perhaps be room for one or two additional social indicators. He also referred to the North -European network project SOSIN - Social Indicators in forestry- which has started a process to discuss the social dimension in sustainable natural resource/forest management.

\subsubsection{References}

Bell, S. et al. (eds.) 2009. European forest recreation and tourism. A handbook. London: Taylor \& Francis.

Bischoff, A. et al. 2007. Friluftsliv og Helse. En kunnskapsoversikt. Bø: Høgskolen i Telemark.

Cordell, H. K. et al. (eds.) 1999. Outdoor Recreation in American Life. A National Assessment of Demand and Supply Trends. Illinois: Sagamore.

Driver, B. L. et al. (eds.) 1991. Benefits of Leisure. Pennsylvania: Venture Publ.

Emmelin, L. et al. 2010. Planera för friluftsliv. Natur, Samhälle, Upplevelser. Stockholm: Carlssons.

Gundersen, V. \& Aasetre, J. 2008. Verdier i bynære skoger. Oppdragsrapport 26. Ås: N. Inst. For Skog og landskap.

Jackson, E. L. \& Burton, T. L. (eds.) 1999. Leisure Studies. Prospects for the TwentyFirst Century. Pennsylvania: Venture Publ.

Jensen, F.S. 2003 Friluftsliv i 592 skove og andre naturområder. Skovbrugsserien nr 32, Skov og Landskap.

Kajala, L. et al. 2007. Visitor monitoring in nature areas - a manual based on experiences from the Nordic and Baltic countries. TemaNord 534. Copenhagen: Nordic Council of Ministers/Stockholm: Naturvårdsverket

Kaltenborn, B. P. \& Vorkinn, M. (eds.) 1993. Vårt friluftsliv. Lillehammer: NINA

Kurtze et al. 2009. Analyse og dokumentasjon av friluftslivet effekt på folkehelse og livskvalitet. Rapport A11851. Trondheim: SINTEF.

Manfredo, M. J. et al. (eds.) 2004. Society and Natural Resources. A Summary of Knowledge (ISSRM). Missouri: USDA Forest Service.

Manning, R. E. 1997. Studies in Outdoor Recreation. Search and Research for Satisfaction. Corvallis: Oregon State University Press.

Sievänen, T. et al. (eds.) 2013 (in prep). Social Indicators in the Forest Sector in Northern Europe - A Review focusing on Nature-based Recreation and Tourism. Working paper. METLA (Finnish Forest Research Institute).

Tyrväinen et al. 2005. Benefits and uses of urban forests and trees. In: Konijnendijk, C.C. et al. (Eds.), Urban Forests and Trees, Berlin: Springer Verlag. 



\section{Session 3 \\ How to value and incorporate values into decision making? Focus on tools and mechanisms}

In session 3, research, information, experiences with practical applications and on-going work on valuation in the Nordic countries were presented by six presenters.

\subsection{How information on the value can contribute to sustainable policy making}

Paula Horne, Pellervo Economic Research, discussed how information on the value of ecosystem services can contribute to sustainable policy making. She started her presentation by describing ecosystem services (ES) as market and non-market goods and services provided from ecosystem processes, giving benefits for people. ES contribute to economic welfare by contribution to benefits (generation of income and wellbeing) and preventing costs (avoiding damage). ES affect people directly and indirectly (by intermediate goods and services). Human activities, such as forest management, affect ecosystem processes. Different forest ecosystem services (like timber, bioenergy, Christmas trees, game, berries, scenery, water regulation, prevention of noise and carbonsequestration) give benefits to different groups/people (owners, industry, consumers, citizens, local community, global community etc.), but all ES contribute to the national economy.

Who benefits from ES may be considered, but ES are a joint production, and ecosystems produce a basket of ES. The key factor is trade-offs; focusing on one ecosystem service in management can deteriorate the production of other ES. The changes are often not immediate, thus time is a key element in impact appraisals when assessing ES. Management in the past affects biodiversity at present (e.g. extinction debt). Furthermore ,the geographical scale and target groups could also be different. 
Environmental values without market value have often been overseen in Environmental Impact Assessments. Many ES do not have market values and are therefore not visible. Environmental concern has often been seen as a constraint to projects, not a benefit. Horne stated that policy appraisals should fully take into account the costs and benefits to the natural environment, highlighting much more clearly the implications for human wellbeing, and identifying the geographical scale and targets groups of changes.

Valuation contributes to better informed decision making, e.g. by providing information about the economic importance of the services. Economic language "speaks best", and full cost-benefit would call for economics to measure benefits or harmful impacts (although not that easy). Valuation would also contribute by suggesting the amount of compensation to those who are harmed by decision making, and by establishing constraints on decision making. Awareness of ecological thresholds is important. If you want to optimize some ES, others may be treated as constraints (by use of economic theory). Uncertainty of outcomes is important to address, as well as the possibility of substitution. Some ES are intermediate services for the whole system and they need special care e.g. by leaving buffer zones.

Additionally, valuation raises questions like: what to do with restricted resources in a society? Shall we forego some social benefits in order to preserve (all) biodiversity and ES? What are the impacts of alternative sources of income? Does democracy (people's preferences) matter? And how do they change over time? How should uncertainty and risk be handled? These are cross disciplinary issues. The usefulness of threatened species in ES was questioned by Horne. Is every species/genetic base equally important? Should we focus on (threatened) species or ecosystem functioning?

Valuation could feed into different kinds of policy issues. How different use/management of ecosystems may affect their ES was illustrated for marshland (national park/forested/set aside) and forest (national park/intensive commercial forest/multifunctional forestry), showing that different use of marshland gave different baskets of ES, while different use of forests provided more similar baskets of ES in a long term perspective (in the short term, however, a decision to clear-cut gave changes in forest ES e.g. scenery, carbon-sequestration).

Horne discussed the challenges of valuing the intermediate ES, as in timber production. Certain ES depend on other ES but also produce other ES. Timber production depends on biodiversity, regulating services (decomposition) and supporting services (photosynthesis, nutrient cy- 
cling), but also produces other ES as supporting services (flood control, erosion prevention, carbon-sequestration), cultural services (recreation, scenery) and production services (berries, game). The value of the intermediate inputs in timber production and the value of ES in joint production are important to focus on.

She concluded by stating that by valuing ES we aim at measuring the value and welfare impact of marketed and non-marketed goods and services. A prior appraisal of the impacts of policies and management decisions and land use changes on the value of ES, and thus welfare is also an aim, so that the change in welfare can be taken into account in decision making and in developing policy instruments.

\subsection{Experiences from the use of different assess- ment tools regarding the value of biodiversity and ecosystem services in Denmark}

Niels Strange, University of Copenhagen, presented and discussed experiences from Denmark with regards to valuation of different ecosystem services, and with a special focus on biodiversity. He also presented tools for making trade-offs. He referred to challenges with regard to valuation, and emphasized that the degree of scarcity is important for the value of a resource, but that we often do not know the function between the two.

He presented examples from studies on valuation of biodiversity in Danish moorlands, Danish National parks (quality and access), access and abundance of game and wildlife and sustainable forest management. Additionally, examples of valuation studies on water, recreation and carbon sequestration were shown.

He pointed to some results from valuation studies based on Willingness to pay (WTP.) Such surveys may give useful information for decision-making, and sometimes information that is different from what is expected. People in Denmark value the cultural landscape highly, and distance to an area is often important. But in a survey of people's view on selecting national parks, they value "wild and remote" parts of Denmark higher than sites closer to population centers, and they were not in favour of human-made landscape as extra roads and paths.

The study on sustainable forest management showed that people have a high willingness to pay for more variation in the landscape. They value mixed deciduous forests higher than homogenous coniferous 
forsts. People have a negative attitude to dead wood, but if they get more information about the connection to biodiversity they are more positive.

He pointed out that the values people assign seem sensitive to the information given in the study. Studies show the Charisma-effect giving higher values on the more charismatic (iconic) species. Significantly higher values were given to species with names/good looking species, compared to (unknown) species with no names. To avoid such effects, it was recommended to go for general rather than specific species unless that is what is intended.

He also presented another approach, cost effective analyses, that has been used to analyze cost-effective conservation efforts of biodiversity protection in Denmark. In the study information on the spatial distribution of almost 900 terrestrial species, species habitat preferences, spatial distribution of main habitats and the efficiency and social cost of specific measures to conserve biodiversity in different habitats is integrated. The analysis shows that forests are important for protecting biodiversity in Denmark. Only 1 species is obligate to agricultural land, but 186 are obligate to forest (There are small forest areas left in Denmark compared to agricultural areas). It matters where the effort is applied. Based on ecological (species and species habitat preferences) and economic data (costs for implementing measures), the project identifies the most costeffective areas for action. The areas are divided into areas where one can "trade" (flexible areas because of alternatives with regards to habitats, although more expensive), and areas that are not-flexible. Due to limited trade-offs between areas and habitat types and little flexibility in policy implementation, regulatory systems are needed to maintain ecosystems/species. The study has also made a gap-analysis which shows that current policies within Natura 2000 and outside of Natura 2000 are not sufficient, and that more focus on forests is needed to cover all species.

He pointed out that there are challenges related to securing biodiversity and socioeconomic values in Danish forests. There is a discussion about how to optimize multiple objectives related to forest ecosystem goods and services. Shall we share (multi-functional areas) or split areas to provide the different ecosystem services timber, biodiversity, Csequestration, water, recreation?

Towards the end he presented some thoughts about another model for analyzing trade-offs. The InVEST model (GIS- software) is a tool for decision- making that makes it possible to visualize the benefits geographically, and also to present the winners and losers at different scale.

At the end he discussed challenges about valuation. The non-use values play a crucial role in valuing biodiversity. Stated preference tech- 
niques (WTP) are the most used methods, but may be hypothetical biased. How do people interpret and value biodiversity, and what are the implications for science and management? With regard to decision making, the issue of scale is a challenge. How can national values be implemented into local problems? Linking national survey values with decision making at different spatial levels, and also at different temporal scales represents a challenge.

\subsubsection{References}

Anthon, S., Thorsen, B.J., Helles, F. 2005. Urban-fringe afforestation projects and taxable hedonic values, Urban Forestry and Urban Greening, 3, 79-91.

Hasler, B., Lundhede, T.H., Martinsen L., 2007. Protection versus purification - assessing the benefits of drinking water quality. Hydrology Research 38 (4), 373-386.

Jacobsen, J.B., Boiesen, J.H., Thorsen B.J., Strange, N., 2008. What's in a name? The use of quantitative measures versus "Iconised" species when valuing biodiversity. Environmental and Resource Economics, 39(3): 247-263.

Jacobsen, J.B. \& Thorsen, B.J., 2010. Preferences for site and environmental functions when selecting forthcoming national parks. Ecological Economics 69 (7):1532-1544.

Jacobsen, J.B., Lundhede, T.H., Thorsen, B.J., 2012. Valuation of increasing wildlife populations above survival. Biodiversity and Conservation 21:543-563.

Jensen, F.S., 1999. Changes in the forest preferences of the Danish population from 1977 to 1994. In: Jensen, F.S., 1999. Forest recreation in Denmark from the 1970s to the 1990s.

The Research Series 26, The Royal Veterinary and Agricultural University and Forskningscentret for Skov og Landskab, Hørsholm, pp. 129-166.

Nielsen, A.B., Olsen, S.B, Lundhede, T.H., 2007. An economic valuation of the recreational benefits associated with naturebased forest management practices. Landscape and Urban.

Planning 80, 63-71.

Petersen, A H., Strange,N., Anthon,S., Bjørner,T.B., Rahbek, C.,2012. Bevarelse af biodiversiteten i Danmark. En analyse af indsats og omkostninger. Arbejdspapir 2012:2 De Økonomiske Råd.

Strange, N., M. Christensen and J. Heilmann-Clausen, 2004. Some policy implications of biodiversity conservation in Danish natural forests. Scandinavian Journal of Forest.

Research 19(suppl.4), 138-149.

Strange, N., Rahbek, C., Jepsen, J.K., Lund, M.P., 2006. Using farmland prices to evaluate cost-efficiency of national versus regional reserve selection in Denmark. Biological.

Conservation 128, 455-466.

Zandersen, M., Termansen, M., Jensen, F.S., 2007. Evaluating approaches to predict recreation values of new forest sites. Journal of Forest Economics 13, 103-128.

\section{Further reading}

UK National Ecosystem Assessment: UK NEA Synthesis of key findings. EU research project on valuation of forest externalities: www.newforex.org InVEST, Integrated Valuation on Environmental Services and Tradeoffs: http://www.naturalcapitalproject.org/InVEST.html 


\subsection{Non-market values and decision making: Expe- riences from Sweden}

Mattias Boman, Swedish University of Agricultural Sciences (SLU), began with some initial thoughts on how the role of nonmarket values depends on the decision-making context in which society may wish to incorporate them. These contexts could be e.g. litigation, values as tools for authorities implementing political decisions, values as THE main input to the formation of new policies and legislation (Bojö 1995,) or as ONE input along with many others.

Based on Swedish forest research there seems to be increasing demand for non-market valuation from funders and stakeholders and on relevance for decision making in different ways. There is also an emphasis on inter-disciplinary research, multiple use considerations and more social science and economics in traditional natural science domains. Key issues in the current debate where nonmarket values play a role are e.g. adaptive management, bio-economy, and ecosystem services (ES). Current and recent research efforts include Future Forests(an interdisciplinary research programme on the multiple uses of Swedish forests that aims to produce knowledge for a sustainable use of forests), Outdoor recreation in Change (an interdisciplinary research programme (mostly social sciences) that aims to form a solid knowledge base by capturing the changes and dynamics in outdoor recreation), and Heureka (a decision support programme that has developed software for forest management planning and analysis).

The report Default monetary values for environmental change. (Kinell et al. 2010) addresses the need for and the difficulties faced in describing changes in ecosystem services and the environment in monetary terms. According to the report there have been several valuation studies in Sweden, but there are too few studies to satisfy the existing needs in order to value environmental change and impacts on ES. Since there is great demand from authorities to value environmental change, there is a need for more "default" monetary values to value environmental change. There seems to be a conflict between doing advanced "novel" studies for scientific publication, and the need for more "simple" studies for applied use.

Most of the present studies in Sweden come from "the academic world," as only 5 out of 170 studies in the Swedish valuation database (ValueBaseSWE) have been reported to be made explicitly for policy/decision making purposes. (Although values derived in other studies could have been used in policy design at a later stage.) 
The Nordic Environmental Valuation Database (Navrud et al 2007), which aims to create a public database for economic valuation studies in the Nordic countries, contains 60 studies from Sweden (out of 192 in total). The methods most frequently used in Swedish non-market valuation studies are: Stated preference 68\% (methods based on surveys where respondents express their willingness to pay - WTP) and Revealed preference $21 \%$ (methods based on market transactions) (Sundberg \& Söderqvist 2004). Commonly valued nature types and services in Sweden are: water (fishing, water quality), forest (recreation, conservation, hunting) and air (air quality, climate) (Kinell et al 2010).

Boman also presented and discussed some personal experiences from doing valuation studies. These studies varied in origin, from pure scientific interest (valuing wolves), policy oriented work (valuing attainment of national environmental objectives) and stakeholder demand and scientific interests (valuing outdoor recreation, hunting and health effects).

\subsubsection{Examples from the results}

By combining contingent valuation results, cost data, and biological information (Boman et al. 2003), the optimal geographical distribution of a wolf population was identified.

WTP for attaining national environmental objectives was estimated through a national contingent valuation survey. The estimated environmental budget was then disaggregated by using specific indicators. In the study (Boman et al. 2008), the value of forest land protection exceeded the cost by a small margin.

Regarding recreation, a study (Norman et al. 2010) analysed the relationship between forest visits in southern Sweden and travel costs. The study also showed that people have preferences for the tree species composition, as the recreation value increases with the share of "noble" broadleaves. Another study (Boman et al. 2011) comparing moose hunting values over time, showed a significant increase between 1986/87 and 2005/06. This analysis suggests caution in using very old results for e.g. benefits transfers exercises.

\subsection{Concluding remarks}

Boman concluded that the indirect influence of valuation on decision making has probably been most important until now. There were fewer valua- 
tion studies in the past and a fear of "valuing the invaluable" amongst many stakeholders. Today there are many more studies and a greater acceptance for monetary valuation of different environmental services.

He expects an increase in the demand for values useful for decision making/makers, and also an increased need for systematic monitoring of environmental values over time (through official statistics). There is sometimes a mismatch between scientific relevance and decision making relevance. He emphasized that a multi-disciplinary approach is often necessary for increased policy relevance of non-market valuation research.

\subsubsection{Selected references}

Bojö, J. 1985. Kostnadsnyttoanalys av fjällnära skogar: Fallet Vålådalen. Handelshögskolan. Stockholm.

Kinell, Söderqvist \& Hasselström. 2010. Default monetary values for environmental change. Report 6323. Naturvårdsverket. Stockholm.

Sundberg, S. \&Söderqvist, T. 2004. The economic value of environmental change in Sweden.Report 5360. Naturvårdsverket. Stockholm.

Navrud,S., Soutukorva, Å., Söderqvist, T. \& Trædal, Y. 2007. Nordic Environmental Valuation Database: Slutrapport till Nordiska Ministerrådets miljö- och ekonomigrupp. TemaNord 2007:518. Nordiska ministerrådet, Köpenhamn.

Boman, M., Bostedt, G. \& Persson, J. 2003. The bioeconomics of the spatial distribution of an endangered species: The case of the Swedish wolf population. Journal of Bioeconomics5, pp. 55-74.

Boman, M., Norman, J., Kindstrand, C. \& Mattsson, L. 2008. On the budget for national environmental objectives and willingness to pay for protection of forest land.Canadian Journal of Forest Research 38, pp. 40-51.

Norman, J., Ellingson, L., Boman, M. \& Mattsson, L. 2010. The value of forests for outdoor recreation in southern Sweden: Are broadleaved trees important? Ecological Bulletins 53, pp. 21-31.

Boman M, Mattsson L, Ericsson G \& Kriström B. 2011. Moose hunting values in Sweden now and two decades ago: The Swedish hunters revisited. Environmental and Resource Economics 50:515- 530.

\section{More information}

Future Forest: www.futureforests.se

Outdoor Recreation in Change: www.friluftsforskning.se

Heureka: www.slu.se/heureka

ValueBaseSWE: http://www.beijer.kva.se/valuebase.htm

Nordic Environmental Valuation Database: http://www.norden.org/sv/

publikationer/publikationer/2007-518 


\subsection{The potential of participatory multi-criteria analysis in ecosystem services valuation}

Heli Saarikoski, Finnish Environment Institute, started by highlighting the link between ecosystem services (ES) and people's needs, and pointed to a growing interest in multi-criteria analysis (MCA) - both as an alternative and/or supplement to economic valuation.

The presentation was divided into three main parts

- A brief overview of MCA.

- A case study.

- Implications for ES valuation.

\subsubsection{A brief overview}

Saarikoski pointed to the fact that MCA, as opposed to monetary valuation, can handle multiple objectives and incommensurable criteria. She also reminded those present that MCA includes several different methods (mainly differentiated by assumptions about degree of commensurability and compensability between values involved in the analysis).

Saarikoski showed how a value tree is used in MCA to structure the problem to be analyzed. A set of relevant criteria is defined, and how a given alternative affects the criteria is described by assigning scores to each criteria. Scoring is done at the most relevant scale for each criteria. Preferences are expressed by assigning weights to the criteria. The outcome of a MCA is a preferred order of alternatives (sensitive to the weighting of criteria).

\subsubsection{A case study}

Saarikoski showed how MCA had been used in Finland to analyze viable logging potential in Upper Lapland where there existed a conflict between state forestry and reindeer herding. The latter is dependent on the old-growth forest areas for food during winter time.

Saarikoski showed the decision tree that had been created in order to structure the problem at hand, and where sustainable land use was defined as the main goal. She further explained how the criteria selected to analyze and assess how to reach this goal were defined in cooperation with stakeholder groups. The different criteria were scored on different (most relevant) scales for alternative land management options (different combinations of logging and conservation for reindeer herding). The 
weighting of the different criteria was done by using a Swing method in which people were asked to give 100 points to what they perceived as the most important attribute (criteria), and score the rest of the attributes relative to the most important. The weight elicitation was carried out through computer-assisted decision analysis interviews by using HIPRE-software (Mustajoki and Hämäläinen 2000). The analysis identified three main stakeholder groups according to the preference order of the alternatives, depending on which issues they viewed as most important in the weighing. (See the presentation for description of the groups and preferred alternatives).

\subsubsection{Implications for ES valuation}

Advantages of MCA:

- Illustration trade-offs and distributional impacts.

- Captures social and ethical concerns - both qualitative and quantitative measures.

- Can well assist participatory approaches.

- Plural and conditional conclusions - pointing out compromise solutions.

Shortcomings of MCA:

- Ignores the possibility that certain criteria may be better represented as issues of principle, than as utilitarian trade-offs.

- Cannot deal with lexicographic preferences.

- Assumes fixed preferences (participatory processes can help people form these preferences).

In conclusion:

- MCA methods can structure an assessment of a complex problem along both cognitive and normative dimensions, both of which are essential in evaluating ecosystem services (Vatn 2009).

- MCA methods are helpful in illustrating trade-offs between different ecosystem services and the distributional impacts of the decisions to use or conserve ecosystem services. 
- They are also suited well for capturing social and ethical concerns that might escape from monetary valuation approaches.

- Can be used in participatory processes.

- However, they cannot deal with lexicographic preferences.

- Group-based approaches to weight elicitation would help people to form and articulate preferences through dialogue with others.

\subsubsection{References}

Mustajoki, J. \& Hämäläinen, R.P. 2000. Web-HIPRE: Global decision support by value tree and AHP analysis. INFOR 38(3), 208-220.

Mustajoki, J., Saarikoski, H., Marttunen, M., Ahtikoski, A., Hallikainen, V., Helle, T., Hyppönen, M., Jokinen, M., Tuulentie, S., Varmola, M., Vatanen, E., \& Yli-Sirniö, A-L. 2011. Use of Decision Analysis Interviews to Support the Sustainable Use of the Forests in Finnish Upper Lapland. Journal of Environmental Management 92 (6):1550-1563.

Vatn, A. 2009. An institutional analysis of methods for environmental appraisal. Ecol Econ 68, 2207-2215.

\subsection{Forest valuation studies in a Nordic context}

Henrik Lindhjem, Norwegian Institute for Nature Research, introduced three types of trade-offs related to forest ecosystem services, and which will involve different stakeholders and may require different approaches:

- trade-offs between elements in the "timber group", e.g. between timber, bioenergy/wood and biomass for wood-based chemical products.

- trade-offs between elements in the "non-timber group", e.g. between biodiversity, wildlife, carbon sequestration, water, tourism and recreation and other products.

- trade-offs between elements the in "timber group" and elements in the "non-timber group."

His presentation relates to an overview and literature study his team is doing for the Norwegian expert commission on values of ecosystem services (cf. Hessen's presentation), where they will provide a description of Norwegian forest ecosystem services, their significance and value, ecosystem service relationships and trade-offs, and important knowledge gaps. 
Relevant forest ecosystem services that have been identified include food, biodiversity (use and non-use values), timber and other raw materials, climate regulation, water quality and quantity, flood prevention, pollution remediation, energy, amenity values, health, recreation and tourism. Several methods are being used to find values related to these services, broadly grouped as adjusted market prices, contribution to output, avoided costs, revealed preferences and stated preferences. Lindhjem indicated what methods that are being used for different services, and mentioned that he will update an overview he has done earlier on Nordic stated preference studies.

Based on his ongoing survey of Nordic literature on valuation of forest ecosystem services, he presented the following preliminary findings:

- Significant work on provisional services, in particular on raw materials, but also on bioenergy, food (meat, berries and fish) and tourism.

- Some work on cultural services, including on biodiversity (non-use), recreation, hunting/fishing and multiple use forestry.

- Less work on regulating and supporting services, but some efforts on carbon and flood prevention.

He also referred to the soon to be published "TEEB Nordic", which will include a number of references to studies on values on forest ecosystem services in the Nordic countries and which inter alia says something about the economic value of forest products and on data availability on different services in different Nordic countries.

Lindhjem provided some initial thoughts on key service sets where we need to make trade-offs now and in the years to come, and he also reflected on possible trends in supply and demand in the next fifty years or so. He presented five service sets that seem to be particularly significant today and which can also be expected to be important in the next decades:

- Raw materials, which may be expected to become relatively less important.

- Carbon storage, which may be expected to become relatively much more important.

- Recreation and sport around urban areas, which may also be expected to become relatively more important.

- Hunting.

- Biodiversity (existence value). 
As an example, he illustrated how Norway may be facing difficult tradeoffs concerning bioenergy harvesting, showing how areas with high bioenergy potential would seem to overlap with areas with biodiversity "hotspots", high population density and high demand for recreation.

In a final remark he mentioned some knowledge gaps and inter alia referred to the significant work done in the UK National Ecosystem Assessment, doing a broad interdisciplinary study enabling the development of maps and policy tools looking at trade-offs between services and beneficiaries.

\subsubsection{References}

Kettunen, M., Vihervaara, P., Kinnunen, S., D’Amato, D., Badura, T., Argimon, M. and ten Brink, P. (2012) Socio-economic importance of ecosystem services in the Nordic Countries - Synthesis in the context of The Economics of Ecosystems and Biodiversity (TEEB). Nordic Council of Ministers, Copenhagen.

Lindhjem, H. (2007) 20 years of stated preference valuation of non-timber benefits from Fennoscandian forests: A meta-analysis. Journal of Forest Economics 12 (4): 251-277.

Lindhjem, H. og Magnussen K. (2012) Verdier av økosystemtjenester i skog i Norge NINA Rapport 894, $80 \mathrm{~s}$.

\subsection{Ecosystem services in forests - Research and re- search needs}

Per Gundersen, Forest and Landscape, University of Copenhagen, addressed research and research needs in relation to ecosystem services in forest. Gundersen has participated in networks under the Nordic Forest Research Cooperation Committee (SNS). He has coordinated the Centre of Advanced Research on Environmental Services (CAR-ES) that aims at providing scientific knowledge on the impacts of forest management on major environmental services for decision making within the forestry sector. The main environmental services addressed are carbon sequestration, water quality, biodiversity and soil quality. He currently coordinates a network on the Forest Soil Carbon Sink.

MCPFE $^{6}$ has offered a general awareness of these services from forest ecosystems, since a number of principles regarding sustainable forest management (SFM) have been agreed upon. The general objectives of CAR-ES have been to strengthen the knowledge base for counting and

${ }^{6}$ Ministerial Conference on the Protection of Forests in Europe. 
optimizing environmental services in SFM; to quantify the environmental impact of different management strategies and practices in operational ways that can support decision-making; and to improve the knowledge and visibility of the environmental services provided by forests in the public as well as among forest owners and managers.

Forest management has the potential to reduce or avoid pressures and to optimize environmental services provided that the mechanisms behind are known. Multifunctional Sustainable Forest Management means to manage benefits from production (from fiber and non-fiber products), environmental services (carbon sequestration, water quality, biodiversity and soil quality) and social services (recreation, rural development) under different pressures such as climate change, air pollution, (over)- exploitation, herbivores, stochastic disturbances, market/cost, and society demands.

He presented some of the studies that the network has initiated in more detail, to illustrate ongoing and future trends in the environmental services in these systems.

A modeling study (Weslien et al. 2009) looks at different scenarios of increased forest productivity (owing to the use of genetically improved plant material and warmer climate) and warmer climates, and the effects on carbon sequestration, run-off water quality and accumulation of dead wood in a boreal landscape. Assuming a proportional decrease in rotation length, the outputs at landscape level are increased carbon sequestration, reduced dead wood (indicator for biodiversity), and no changes in nutrient losses (no change in water quality).

A study (literature review) on environmental services provided from Riparian Forests (RF) in the Nordic countries was also presented (Gundersen et al. 2010). RF's have special ecological functions in the landscape such as buffering the impacts from upland management (protecting water bodies from nutrients released) and they are important for biodiversity. They also have large soil carbon stores, but may emit more greenhouse gases than the uplands (their net GHG balance is not well known).

At present, afforestation is important in Denmark, and research has been conducted on the development of ecosystem services over time after land use change. It will take a long time (may be several hundred years) to reach biodiversity (species content) corresponding to the old forest, while carbon-sequestration will increase with stand age (although a different/steeper curve for Norway spruce compared to oak).

He also referred to a modeling study soon to be published (Duncker et al. 2012) on how forest management affects ecosystem services that illustrates environmental service interactions through synergies and 
trade-offs. Long term effects on the ability of the forest to provide ecosystem goods and services of five different forest management alternatives were simulated (ranged from non-intervention to intensive silvicultural systems). The study clearly illustrated the complex synergy and trade-offs pattern between ecosystem services. It was illustrated that maximizing the rates of biomass production and carbon sequestration may conflict with protection of biodiversity. But it was also illustrated that several silvicultural operations may have positive effects on biodiversity and water protection without high costs.

Gundersen claimed that the term "Ecosystem services" has put forestry in a more positive light. He emphasized that the Nordic countries have lots of experimental data from the "pollution era" like acid rain forest research, and that such data should be re-used for the purpose of research on ecosystem services. He also emphasized to move focus away from single operations to management systems, from years to rotations, and from stands to landscapes. He pointed to the following perspectives/topics as particularly needed in future research on ecosystem services: modeling activities and modeling development, and methods for analyzing synergies and trade-off between services as well as ecosystem services interactions. He concluded by stating that interdisciplinary cooperation is needed, and that integrated research that also include long term studies at the landscape level is needed.

\subsubsection{References}

Duncker et al. (2012) How Forest Management affects Ecosystem Services, including Timber Production and Economic Return: Synergies and Trade-Offs. Ecology and Society 17(4):50.

Gundersen P. et al. (2010) Environmental services provided from riparian forests in the Nordic countries. Ambio 2010 39:555-566.

Weslien, J. et al. (2009) Effects of increased forest productivity and warmer climates on carbon sequestration, run-off water quality and accumulation of dead wood in a boreal landscape. Scandinavian Journal of Forest Research; 2009 24:333-347.

\section{Nordic research networks}

SNS Network on Environmental Services (CAR-ES):

http://www.nordicforestresearch.org/car-es/_and http://www.nordicforestrycares.org

Forest Soil C-Sink Nordic Network: http://www.nordforsk.org/en/programs/ prosjekter/forest-soil-c-sink-nordic-network?set_language=en

As well as: http://www.cforsoil.org 



\section{Session 4: Directions for the future. Recommendations for future work, research needs etc.}

In session 4 the workshop concluded with a discussion based on questions prepared by the organizers. The questions addressed different topics such as understanding benefits and values, methods to demonstrate value, synergies and trade-offs, as well as proposals for Nordic cooperation and research needs. The views forwarded during the debate represent those of individual participants and do not necessarily reflect agreement in the group as a whole.

\subsection{First discussion: Benefits, values and methodology}

With regard to the question related to the benefits, values, methodological approaches etc., the participants were asked to give viewpoints on shortcomings and issues that need attention, or need to be solved. The discussion is summarized in the following viewpoints:

\subsubsection{Valuation of biodiversity is a complex issue}

A number of valuation methods exist that try to "detect" people's preferences. Some participants recommended caution with regards to monetary valuation. As stated by TEEB, valuation of biodiversity is context specific and a tailored approach is often necessary. Demonstrating value by quantification is possible. Depending on the context, quantification might provide useful information, and it is not necessary to "price".

A problem raised, was that there seems to be a lower value on species that do not have a "known" name. Therefore, advice was given not to use species name in valuation studies (and to be as general as possible), while others were of the opinion that it is difficult to value species which are not known to people. 


\subsubsection{Soil biodiversity}

It was stated that we do not know enough about the value of soil biodiversity and its role in ecological processes.

\subsubsection{Use values vs. existence value.}

The need to address both use values and existence value was stated.

Values of red list species vs. values of species responsible for intermediate services

Another issue raised was the value of threatened/ scarce species vs. species that have an important function (role in intermediate services) in producing services. Intrinsic /existence value may be high, and higher the more scarce the species are. With regard to species that have a role in intermediate services - it may be possible to substitute the species with other species. Scarce species have high intrinsic values - as opposed to - species "responsible" for intermediate services that can be substituted with each other.

\subsubsection{MCA-methodology and knowledge needs with regard to expression of preferences}

Multi-criteria analysis (MCA) can be a good way to handle different values. However, you need informed respondents to assess preferences. Questions were raised whether people who are asked have enough knowledge about the issue? Are they sufficiently informed about what they are going to have preferences on? An issue raised was e.g. how necessary explanations are when surveys are being conducted, and to what extent you need to "transform" ecologic information. There may be a trade-off between how much time the respondent need to spend on questions (comprehensive questions) - and the response rate.

\subsubsection{WTP- methodology and knowledge needs with re- gard to expression of preferences}

The same issues as raised above were also discussed in relation to willingness to pay studies. How well informed are the respondents, and does one control for the respondent's level of knowledge? There may be information attached to questions, and one may check whether they are read, although not how carefully. There may be a trade-off between how much time the respondent need to spend on questions (comprehensive questions) -and the response rate. 


\subsubsection{Different services - trade offs/synergies}

Ecosystem services relate to each other in many different ways, ranging from synergistic, to tolerant, conflicting and mutually exclusive. Tradeoffs often pose difficult choices for society, with different sets of winners and losers depending on the decision. Addressing trade-offs is important, (both trade-offs in relation to time, space, those who win and lose, and between services). Tools and broader frameworks need to be developed. Multiple use consideration was also addressed.

\subsubsection{A combination of different approaches}

As valuation is a challenge for several items," hybrids" that combine different tools and perspectives or complement each other, were discussed. It may be useful to combine different approaches e.g. bio-physical indicators, monetary valuation or participatory methods. This may be useful since they have different strengths and weaknesses. In particular, the question was raised whether it is possible to combine monetary and non-monetary methods? Is it possible to combine monetary approaches with multi-criteria analysis? Information was given about a new project in Finland that has adopted this approach.

\subsection{Second discussion: Knowledge gaps and pro- posals for Nordic cooperation}

With regards to questions related to knowledge gaps and proposals for Nordic cooperation, the discussion is summarized in the following viewpoints.

\subsubsection{We do not know enough about biodiversity}

We don't know enough about biodiversity, especially spatial resolution on biodiversity at different levels; genetic, species and ecosystem, including landscape level. There is definitely not enough knowledge on dose-response relationships and of ecological thresholds. There is also a need to know more about what kind of driving forces that are important in the systems. 


\subsubsection{Linking biodiversity, ecosystem processes/function and ecosystem services.}

There are information gaps and challenges linked to the measurement of ecosystem services provision, e.g. links between biodiversity and ecosystem services. The links between biodiversity and ecosystem services are complex, with many factors influencing ecosystem resilience and capacity to provide services. There is a need for more knowledge of ecosystem structure and function and the link to services. A wide program of research is needed.

\subsubsection{Indicators}

Several participants mentioned the need to develop comparable indicators, and that indicators should be developed in a Nordic cooperation as coherent statistics between countries will raise awareness. Good statistics for ecosystem services is needed, and development of indicators to assess ecosystem services in a Nordic context would enable comparison between the countries.

\subsubsection{Distributive issues}

The distributional aspects of ecosystem services need to be addressed. There is a need to address who will benefit and who loses, and also how the ecosystem services are distributed across time and space. Compensation issues are also of relevance.

\subsubsection{Preservation of soil carbon pools}

We need to preserve soil carbon pools, as soil carbon is a great carbon sink. How to prevent losing carbon from soil?

\subsubsection{Assessment of ecosystem services}

A national assessment of ecosystem services can be a powerful tool that can communicate advice for the future and influence the debate. The UK NEA was referred to as good way of doing this. Case studies here and there, although utilized, would not carry the same weight as national assessment. 


\subsubsection{Green national accounting}

Green national accounting is important, and work on the development of physical accounts should be given more attention. It is a good way to illustrate economic development and the development of the natural capital.

\subsubsection{Sustainable management of ecosystems}

It is necessary to incorporate concerns regarding sustainability within an ecosystem service assessment. Sustainable management of ecosystems needs to be addressed.

\subsection{Concluding words - and further work}

Eli Moen, Norwegian Ministry of Environment, summed up the workshop and gave some closing remarks on behalf of the organizers. She thanked all the participants for active contributions, and concluded that it had been an interesting day with many good presentations and discussions.

The contributions will be followed up by the Nordic Council of Ministers as the Working Group on Terrestrial Ecosystem and the Working group on Environment and Economy will discuss the results and take the discussion further.

Each country needs to develop a national policy on ecosystem services. The Nordic countries are quite similar in many ways, conf. "the Nordic Model." Norway, Sweden and Finland are also in the same biogeographical zones. The tradition of recreation is much the same. Thus Nordic cooperation can also help the Nordic countries in implementing the advice from TEEB and the strategic goals under CBD. 



\section{Kort sammendrag}

En nordisk workshop om vurdering og verdsetting av økosystemtjenester i skog - "Ecosystem Services in Forests - how to assess and value them" ble avholdt i Oslo torsdag 13. september 2012. Seminaret ble arrangert som et ledd i at Norge hadde formannskapet i Nordisk Ministerråd i 2012. Målet med verkstedet var å utveksle kunnskap og erfaringer om ulike metoder for vurdering og verdsetting av økosystemtjenester i skog, med et spesielt fokus på ikke-prissatte varer og tjenester som biologisk mangfold, klimaregulering/karbonbinding og rekreasjon. Det var også et mål å belyse ulike tilnærminger og verktøy for å integrere verdier av økosystemtjenester i beslutningsprosesser i de nordiske landene.

Verkstedet samlet deltakere fra forskning, forvaltning og politikkutforming, samt andre som er opptatt av vurdering og verdsetting av økosystemtjenester i skog. I løpet av dagen ble det holdt 13 presentasjoner, og de i alt 41 deltakerne fikk anledning til å diskutere veien videre og formulere utfordringer og mulige framtidige forskningsoppgaver som anbefalinger til Nordisk Ministerråd. Denne rapporten presenterer et sammendrag av presentasjonene og gir en kort oppsummering av spørsmålene som ble diskutert. Verkstedet belyste så vel kjent kunnskap om økosystemtjenester, som utfordringer og muligheter knyttet til utredninger og verdivurderinger, og deltakerne ble utfordret til å ta opp nye og viktige problemstillinger på sine respektive fagfelt.

Verkstedet ble gjennomført i fire sesjoner. I den første sesjonen ble det presentert bakgrunnsinformasjon for verkstedet, inkludert forventninger og politiske føringer for tilnærmingsmåter og metoder for å vurdere og verdsette økosystemtjenester. I den andre sesjonen ble tre viktige økosystemtjenester i de nordiske landene - biologisk mangfold, karbonbinding og rekreasjon - presentert mer i detalj. Den tredje sesjonen omhandlet erfaringer fra de nordiske landene når det gjelder vurdering, synliggjøring og økonomisk verdsetting av økosystemtjenester, og hvordan disse verdiene kan innarbeides i beslutningsprosesser. Den fjerde sesjonen omfattet en diskusjon om viktige temaer og forslag til framtidige arbeids- og forskningsoppgaver. Ut fra informasjon som ble presentert på seminaret og sin egen kompetanse, diskuterte deltakerne spørsmål som var reist av arrangørene. 


\section{Avsluttende bemerkninger}

Vår kunnskap og forståelse om biologisk mangfold og verdien av økosystemtjenester er økende, men det er fortsatt en lang vei å gå før de nordiske landene kan oppfylle de vedtatte målene i konvensjonen om biologisk mangfold (CBD), som sier at biologisk mangfold skal integreres i nasjonale og lokale utviklings- og planleggingsprosesser og innlemmes i nasjonale regnskaps- og rapporteringssystemer. Det er behov for å øke vår kunnskap om viktigheten og verdien av økosystemtjenester og om hvordan denne kunnskapen kan bli bedre integrert i alle relevante beslutningsprosesser. Dette verkstedet har vært et skritt på veien til å øke vår forståelse om disse spørsmålene. 


\section{Utvidet sammendrag}

En nordisk workshop om vurdering og verdsetting av økosystemtjenester i skog - Ecosystem Services in Forests - how to assess and value them ble avholdt i Oslo torsdag 13. september 2012. Seminaret ble arrangert som et ledd i at Norge hadde formannskapet i Nordisk Ministerråd i 2012. Målet med verkstedet var å utveksle kunnskap og erfaringer om ulike metoder for vurdering og verdsetting av økosystemtjenester i skog, med et spesielt fokus på ikke-prissatte varer og tjenester som biologisk mangfold, klimaregulering/karbonbinding og rekreasjon. Det var også et mål å belyse ulike tilnærminger og verktøy for å integrere verdier av $\emptyset$ kosystemtjenester i beslutningsprosesser i de nordiske landene.

Verkstedet samlet deltakere fra forskning, forvaltning og politikkutforming, samt andre som er opptatt av vurdering og verdsetting av økosystemtjenester i skog. I løpet av dagen ble det holdt 13 presentasjoner, og de i alt 41 deltakerne fikk anledning til å diskutere veien videre og formulere utfordringer og mulige framtidige forskningsoppgaver som anbefalinger til Nordisk Ministerråd. Denne rapporten presenterer et sammendrag av presentasjonene og gir en kort oppsummering av spørsmålene som ble diskutert. Verkstedet belyste så vel kjent kunnskap om økosystemtjenester, som utfordringer og muligheter knyttet til utredninger og verdivurderinger, og deltakerne ble utfordret til å ta opp nye og viktige problemstillinger på sine respektive fagfelt.

Verkstedet ble gjennomført i fire sesjoner.

I den første sesjonen ble det presentert bakgrunnsinformasjon for verkstedet, inkludert forventninger og politiske føringer for tilnærmingsmåter og metoder for å vurdere og verdsette økosystemtjenester. Som en oppfølging av FN-studiene Millennium Ecosystem Assessment (MA) og The Economics of Ecosystems and Biodiversity (TEEB ) er det nedfelt flere overordnede politiske forpliktelser om at alle verdier knyttet til biologisk mangfold og økosystemtjenester skal integreres i beslutningsprosesser (som er gjenspeilet i vedtatte mål under konvensjonen om biologisk mangfold, CBD). Det ble også trukket fram en del utfordringer og muligheter knyttet til verdsetting (som økosystemkompleksitet, resiliens (elastisitet og robusthet) og ikke-linearitet, diskonteringsrentens rolle, usikkerhet knyttet til verdsettingsmetoder og folks preferanser over tid, samt institusjonelle rammeverk). Begrepet økosystem- 
tjenester kan bidra til at vi klarere ser og forstår vår avhengighet av naturen. Skog ble valgt som tema for verkstedet, fordi skogøkosystemer er viktig for menneskelig velferd, og fordi skog er viktige økosystemer i de nordiske landene. Politiske utfordringer i bærekraftig skogforvaltning (Sustainable Forest Management, SFM) ble diskutert, herunder behovet for balansert og dynamisk forståelse av økonomiske, miljømessige og samfunnsmessige verdier. Viktige utfordringer for SFM i dag er blant annet skog og klimaendringer og utvikling av tilstrekkelige tilpasninger og avbøtende tiltak, og styrking av biologisk mangfold gjennom økt vern og bedre integrert skogforvaltning. Kriterier for bærekraftig skogbruk er etablert, men trenger å videreutvikles.

I den andre sesjonen ble tre viktige økosystemtjenester i de nordiske landene - biologisk mangfold, karbonbinding og rekreasjon - presentert mer i detalj.

Naturverdiene i skog har stor betydning, ettersom ca. 60 prosent av alle kjente arter lever i skog. Det foregår også viktige økosystemprosesser i skog. Ulike mål for forvaltning av skog kan avveies og balanseres gjennom bevaring av ulike økosystemtjenester i skog. Et sentralt spørsmål er hvordan sammensetningen av biodiversiteten kan relateres til økosystemtjenester. Noen koblinger mellom biologisk mangfold og økosystemtjenester er kjent, men for de fleste av de biologiske komponentene kjenner vi ikke sammenhengene.

Skog (skogsjord og vegetasjon) spiller en nøkkelrolle i den globale karbonbalansen og atmosfærisk $\mathrm{CO}_{2}$-konsentrasjon. Uten karbonlagre i skog ville vi hatt raskere klimaendringer, med mer alvorlige effekter på økosystemer og samfunn. Nivået på karbonbinding i skog avgjøres gjennom hvordan vi forvalter skogen. Studier viser at det er mulig å finne vinn- vinn-løsninger for karbonbinding og andre økosystemtjenester (for eksempel ivaretakelse av biologisk mangfold), og at synergier bør analyseres systematisk.

Skog er svært viktig for rekreasjon, ettersom skog er den typen naturområde som hyppigst brukes til (daglig) friluftsliv i de fleste nordiske land. Vi har gode data om dette på nasjonalt nivå i de nordiske landene, men mangler informasjon om bl.a. bruk, brukertilfredshet og samfunnsmessige konsekvenser på lokalt nivå.

Den tredje sesjonen omhandlet erfaringer fra de nordiske landene når det gjelder vurdering, synliggjøring og økonomisk verdsetting av økosystemtjenester, og hvordan disse verdiene kan innarbeides i beslutningsprosesser.

Noen tendenser fra de nordiske landene knyttet til vurdering, synliggjøring og økonomisk verdsetting ble trukket fram. Det er en økende 
bevissthet om behovet for å forstå, beskrive, måle og verdsette de ulike økosystemtjenestene. Synliggjøring og verdsetting kan bidra til bedre beslutningsgrunnlag for vedtak, for eksempel ved å gi informasjon om den økonomiske betydningen av tjenestene.

Verkstedet synliggjorde at de nordiske landene har en viss erfaring med økonomisk verdsetting av forsynende tjenester og likedan kulturelle tjenester, men at det har vært arbeidet mye mindre med å verdsette regulerende og støttende tjenester.

Vitenskapsmiljøer opplever økt påtrykk fra myndighetene på å sette en verdi på endringer i miljøet. Det synes å være en økende etterspørsel etter vurdering av ikke-prissatte konsekvenser så vel fra de som skal finansiere tiltakene som fra interessenter, og større fokus på slike verdivurderingers relevans i ulike beslutningsprosesser. Det legges større vekt på tverrfaglig forskning og flerbrukshensyn, og mer vekt på samfunnsfag og økonomi innenfor tradisjonelle naturvitenskapelige domener. Det pågår også forskning som kan bidra til beslutningstaking/bærekraftig forvaltning, men så langt har den indirekte påvirkningen av verdsetting på beslutningsprosesser trolig vært det viktigste. (Tidligere ble det gjort færre verdsettingsstudier og det var blant mange interessenter en frykt for å "verdsette det uvurderlige." I dag gjøres det langt flere studier, og det er også en større aksept for økonomisk verdsetting av ulike miljøtjenester.)

Når det gjelder metoder, viste verkstedet at økosystemtjenester kan synliggjøres og verdsettes på flere måter. Det er ulike muligheter og begrensninger rundt hvordan de kan verdsettes, avhengig av datatilgjengelighet og metodikk. For mange økosystemtjenester er det for lite kunnskap, for andre kan det gis en kvalitativ vurdering, noen kan kvantifiseres, og for noen få vil det være mulig å verdsette i kroner og øre. Valg av metode avhenger blant annet av i hvilken kontekst de skal brukes. (F.eks. som verktøy for politikkutvikling / implementering av politiske beslutninger, rettstvister, som en egen komponent i beslutningsprosesser, eller sammen med andre.)

Det finnes ulike ikke-markedsbaserte metoder for synliggjøring og verdsetting, som kvalitative, kvantitative, monetære (oppgitte preferanser, avslørte preferanser, kostnadsbaserte tilnærminger), multikriterieanalyser og medvirkende og rådgivende prosesser. I løpet av verkstedet ble det presentert ulike tilnærminger til forskning og beslutningsstøttesystemer (fysiske miljøregnskap, betalingsvillighetsundersøkelser, kostnadseffektivitetsanalyser, InVest-modellen, multikriterieanalyser osv.). 
Når det gjelder økonomiske verdsettingsstudier i de nordiske landene, er ulike metoder for å analysere oppgitte preferanser mest brukt, og deretter analyser av avslørte preferanser.

Utvikling av multikriterierelaterte tilnærminger i miljøforskning er et område i stadig utvikling. I motsetning til monetær verdsetting, kan disse metodene håndtere flere mål og usammenlignbare kriterier. De kan også brukes i samarbeidsprosesser, der metodene kan være nyttige til å illustrere avveininger og prioriteringer.

Andre aktuelle temaer ble også tatt opp. Verkstedet bekreftet behovet for å utvikle metoder og verktøy, og for å komme fram til resultater som er nyttige for de som skal utforme eller fatte beslutninger - inkludert en mer systematisk oppfølging av miljøverdier over tid, f.eks. gjennom offentlig statistikk

Behovet for mer integrert forskning som også inkluderer langtidsstudier på overordnet nivå, ble tatt opp, samt en vurdering av den virkningen politiske og forvaltningsmessige beslutninger og endringer i arealbruk kan få på verdien av økosystemtjenester. Bevissthet om økologiske terskler (vippepunkter) er viktig. Det faktum at folks preferanser, atferd og valg kan endre seg over tid, representerer en spesiell utfordring.

Behovet for flerfaglige tilnærminger og tverrfaglig samarbeid ved evaluering og verdisetting av økosystemtjenester ble tatt opp av flere foredragsholdere da en flerfaglig tilnærming ofte er nødvendig dersom ikke-markedsbaserte verdsettingsmetoder skal få økt politisk betydning.

Et annet forhold som ble tatt opp av flere av foredragsholderne, var behovet for å anerkjenne og forstå avveininger og prioriteringer, i forhold til tid og rom, hvem som vinner og taper, og mellom tjenester. Det er mulig å vurdere hvem som drar nytte av en tjeneste, men ettersom $ø$ kosystemer produserer en rekke tjenester på samme tid, er avveininger og prioriteringer et sentralt tema. Når det fokuseres på produksjon av en bestemt $ø$ kosystemtjeneste, kan produksjonen av andre tjenester bli påvirket, og det ble etterlyst systemer for integrert forvaltning, integrert forskning og systemer for å ivareta flere mål. Tid, geografisk skala og målgrupper er sentrale elementer i vurderingen av økosystemtjenester. Det ble påpekt at tidligere forvaltning påvirker dagens biologiske mangfold (f.eks. er det snakk om en "utrydningsgjeld"). Men som noen studier viser, er det også mulig å identifisere vinn-vinn-løsninger, som med karbonbinding og biodiversitet eller andre økosystemtjenester. Det ble også påpekt at flere skogkulturtiltak kan ha positive effekter på biologisk mangfold uten at det medfører høye kostnader.

Den fjerde sesjonen omfattet en diskusjon om viktige temaer og forslag til framtidige arbeids- og forskningsoppgaver. Ut fra informasjon 
som ble presentert på seminaret og sin egen kompetanse, diskuterte deltakerne spørsmål som var reist av arrangørene.

Det ble formidlet flere synspunkter på temaer/problemstillinger som må diskuteres eller løses. Punkter som ble tatt opp inkluderte f.eks. synergier og avveininger/prioriteringer mellom ulike økosystemtjenester, vinnere og tapere avhengig av beslutninger/fordelingshensyn, informasjonsbehov i multi-kriterieneanalyser og i betalingsvillighetsanalyser, kunnskap om biodiversitet, koblingen mellom biologisk mangfold og økosystemtjenester, økosystemkompleksitet og økologiske terskler, verdivurdering av innsatstjenester, og rollen til og verdien av biodiversitet i jordsmonn.

I tillegg kom det fram flere synspunkter på kunnskapshull og forslag til nordiske samarbeidstemaer. Verkstedet identifiserte økt kunnskap om biologisk mangfold og koblingen mellom biologisk mangfold, økosystemprosesser/- funksjoner og økosystemtjenester som viktige elementer for framtidig forskning. Flere av deltakerne foreslo å utvikle og etablere felles indikatorer for økosystemtjenester gjennom nordisk samarbeid. Dette kan også bidra til videreutvikling av tilleggskriterier og indikatorer for bærekraftig skogbruk.

Metoder for å analysere synergieffekter og avveininger/prioriteringer mellom tjenester, og fordelingsspørsmål med hensyn til hvem som tjener og taper på en beslutning, ble også foreslått som framtidige temaer for nordisk samarbeid. Videre ble grønt nasjonalregnskap vurdert som et aktuelt tema for samarbeid innenfor en nordisk ramme. Spørsmål knyttet til bevaring av jordkarbonlagre og bærekraftige forvaltning var også blant de temaene som ble foreslått.

\section{Avsluttende bemerkninger}

Vår kunnskap og forståelse om biologisk mangfold og verdien av økosystemtjenester er økende, men det er fortsatt en lang vei å gå før de nordiske landene kan oppfylle de vedtatte målene i konvensjonen om biologisk mangfold (CBD), som sier at biologisk mangfold skal integreres i nasjonale og lokale utviklings- og planleggingsprosesser og innlemmes i nasjonale regnskaps- og rapporteringssystemer. Det er behov for å øke vår kunnskap om viktigheten og verdien av økosystemtjenester og om hvordan denne kunnskapen kan bli bedre integrert i alle relevante beslutningsprosesser. Dette verkstedet har vært et skritt på veien til å øke vår forståelse om disse spørsmålene. 



\section{List of annexes}

Annex 1: Programme for the workshop 13 ${ }^{\text {th }}$ September 2012 Nordic Workshop on Ecosystem services in forests - how to assess and value them?

Thon Hotel Opera, Oslo, Thursday 13 September 2012

\section{Programme}

Welcome by Henriette Westhrin, State Secretary, Ministry of Environment, Norway

Session 1:

Introductory presentations

(Chair: Eli Moen, Norwegian Ministry of Environment, Member of the Nordic Council of Ministers Working Group on Terrestrial Ecosystem)

Hilde Kyrkjebø (Norwegian Directorate for Nature Management): Setting the scope

Knut Øistad Ministry of Agriculture and Food, Norway: Policies for sustainable forest management in Europe

Coffee break

Session 2:

Forest Ecosystem Services

(Chair: Else Løbersli, Norwegian Directorate for Nature Management)

Presentation of benefits to society that forests ecosystem can provide, and with a special attention to biodiversity, climate regulation/carbon sequestration and recreational services.

Erik Framstad, Norwegian Institute for Nature Research (NINA): Biodiversity and links to other ecosystem services

Raisa Mäkipää, The Finnish Forest Research (METLA): Carbon sequestration

Odd Inge Vistad, Norwegian Institute for Nature Research (NINA): Recreation

Questions and comments

Lunch $11.30-12.30$ 
Session 3:

How to value and incorporate values into decision making? Focus on tools and mechanisms (Chair: Øyvind Lone, Norwegian Ministry of Environment, Chairman of the Nordic Council of Ministers Working group on Environment and Economy)

Paula Horne, Pellervo Economic Research (PTT): How information on the value can contribute to sustainable policy making

Niels Strange, Forest \& landscape Denmark: Experiences from the use of different assessment tools regarding the value of ecosystem services in Denmar

Mattias Boman, Swedish University of Agricultural Sciences (SLU): Non-market values and decision making: Experiences from Sweden

Heli Saarikoski, Finnish Environment Institute (SYKE): The potential of participatory multi-criteria analysis in ecosystem services valuation

Henrik Lindhjem, Norwegian Institute for Nature Research (NINA)/Vista: Forest valuation studies in a Nordic context

Per Gundersen, Forest \& landscape Denmark: Research and research needs

Questions and comments

Coffee break

Session 4

Direction for the future. Recommendations for future work, research needs, etc. (Chair: Øyvind Lone, Norwegian Ministry of Environment, Chairman of the Nordic Council of Ministers Working group on Environment and Economy

Plenary discussion

Eli Moen (Norwegian Ministry of Environment, and member of the Nordic Council of Ministers Working Group on Terrestrial Ecosystem): Concluding words - and further work

\subsection{Annex 2: Links to the presentations}

You can find the power-point presentations from the Nordic workshop on Ecosystem services in forests - how to assess and value them, $13 \mathrm{Sept}$ 2012 on the following link:

- http://www.miljødirektoratet.no/no/Tema/Arter-og-naturtyper/ Verdien-av-naturmangfold-og-okosystemtjenester/Nordiskworkshop-om-okosystemtjenester-i-skog/ 


\subsection{Annex 3: List of participants}

\begin{tabular}{|c|c|c|c|}
\hline Etternavn & Fornavn & Organisasjon/Etat & E-post \\
\hline Bergseng & Even & Norwegian University of Life Sciences & even.bergseng@umb.no \\
\hline Bodsberg & Kristin & Norwegian Directorate for Nature Management* & kristin.bodsberg@dirnat.no \\
\hline Boman & Mattias & Swedish University of Agricultural Sciences - SLU & mattias.boman@slu.se \\
\hline Brendemoen & Anne & Ministry of Environment, Norway & anne.brendemoen@md.dep.no \\
\hline Dahl & Reidar & Norwegian Directorate for Nature Management* & reidar.dahl@dirnat.no \\
\hline de Wit & Heleen & Norwegian Institute for Water Research & heleen.de.wit@niva.no \\
\hline Ederlöf & Erik & Swedish Forest Agency & erik.ederlof@skogsstyrelsen.se \\
\hline Framstad & Erik & $\begin{array}{l}\text { Norwegian Institute for Nature Research - } \\
\text { NINA }\end{array}$ & Erik.Framstad@nina.no \\
\hline Garnåsjordet & Per Arild & Statistics Norway & PerArild.Garnasjordet@ssb.no \\
\hline Granath & Fredrik & Swedish Environmental Protection Agency & fredrik.granath@naturvardsverket.se \\
\hline Grimsrud & Kristine & Statistics Norway & kristine.grimsrud@ssb.no \\
\hline $\begin{array}{l}\text { Grønvik } \\
\text { Bråten }\end{array}$ & Kirsten & Ministry of Environment, Norway & Kirsten-Gronvik.Braten@md.dep.no \\
\hline Gundersen & Per & Forest and landscape Denmark & pgu@life.ku.dk \\
\hline Haugland & Hege & Climate and Pollution Agency* & Hege.Haugland@klif.no \\
\hline Hessen & Dag & $\begin{array}{l}\text { Expert commision on values of ecosystem } \\
\text { services, University of Oslo }\end{array}$ & \\
\hline Horne & Paula & Pellervo Economic Research PTT, Finland & paula.horne@ptt.fi \\
\hline Karlog & Pernille & Naturstyrelsen, Miljøministeriet & pka@nst.dk \\
\hline Katerås & Finn & Ministry of Environment, Norway & Finn.Kateras@md.dep.no \\
\hline Kyrkjeb $\varnothing$ & Hilde & Norwegian Directorate for Nature Management* & hilde.kyrkjebo@dirnat.no \\
\hline Lindhjem & Henrik & $\begin{array}{l}\text { Vista Analyse/Norwegian Institute for Nature } \\
\text { Research - NINA }\end{array}$ & Henrik.Lindhjem@nina.no \\
\hline Lone & $\varnothing$ yvind & Ministry of Environment, Norway & oyvind.lone@med.dep.no \\
\hline Løbersli & Else & Norwegian Directorate for Nature Management* & Else.Lobersli@DIRNAT.NO \\
\hline Moen & Eli & Ministry of Environment, Norway & Eli.Moen@md.dep.no \\
\hline Mäkipää & Raisa & The Finnish Forest Research Institute -METLA & Raisa.Makipaa@metla.fi \\
\hline $\begin{array}{l}\text { Wannebo } \\
\text { Nilsen }\end{array}$ & Kjersti & Norwegian Directorate for Nature Management* & kjersti.nilsen@dirnat.no \\
\hline Saarikoski & Heli & Finnish Environment Institute - SYKE, Finland & Heli.Saarikoski@ymparisto.fi \\
\hline Schröter & Matthias & Wageningen University/NINA & matthias.schroter@wur.nl \\
\hline Selboe & Odd Krstian & Norwegian Directorate for Nature Management* & Odd-Kristian.Selboe@DIRNAT.NO \\
\hline Slotte & Håkan & The Swedish National Heritage Board & hakan.slotte@raa.se \\
\hline Solås & Asbjørn & Ministry of Environment, Norway & asbjorn.solas@md.dep.no \\
\hline Stokland & Jogeir & Norwegian Forest and Landscape Institute & jogeir.stokland@skogoglandskap.no \\
\hline Strange & Niels & Forest and landscape Denmark & nst@life.ku.dk \\
\hline Sundal & Kristin & Norwegian Directorate for Nature Management* & kristin.sundal@dirnat.no \\
\hline $\begin{array}{l}\text { Sverdrup- } \\
\text { Thygeson }\end{array}$ & Anne & The Department of Ecology and Natural Resource & anne.sverdrup-thygeson@umb.no \\
\hline Sæther & Bent Arne & Ministry of Environment, Norway & bent-arne.sather@md.dep.no \\
\hline Tunaal Withe & Lajla & Ministry of Environment, Norway & lajla-tunaal.withe@md.dep.no \\
\hline Vea & Reidun & Directorate for Cultural Heritage & reidun.vea@ra.no \\
\hline Vistad & Odd Inge & $\begin{array}{l}\text { Norwegian Institute for Nature Research - } \\
\text { NINA }\end{array}$ & odd.inge.vistad@nina.no \\
\hline Westhrin & Henriette & State Secretary, Ministry of Environment, Norway & \\
\hline Wiese & Inger Johanne & Ministry of Environment, Norway & ijw@md.dep.no \\
\hline$\varnothing$ istad & Knut & Ministry of Agruculture and Food, Norway & Knut.Oistad@Imd.dep.no \\
\hline
\end{tabular}

*From 1 July 2013 Norwegian Environment Agency. 


\subsection{Annex 4: Relevant reports and websites}

\section{Relevant reports etc. from the Nordic Council of Ministers}

Framstad, E., de Wit, H., Mäkipää, R., Larjavaara, M., Vesterdal,l., Karltun, K.(2013), Biodiversity, carbon storage and dynamics of old northern forests. Nordic Council of Ministers, Copenhagen.

TemaNord 2013:507

Kettunen, M., Vihervaara, P., Kinnunen, S., D’Amato, D., Badura, T., Argimon, M. and ten Brink, P. (2012) Socio-economic importance of ecosystem services in the Nordic Countries - Synthesis in the context of The Economics of Ecosystems and Biodiversity (TEEB). Nordic Council of Ministers, Copenhagen.

Nordic Environmental Valuation Database: http://www.norden.org/sv/ publikationer/publikationer/2007-518

\section{Relevant websites}

EU research project on valuation of forest externalities: www.newforex.org FOREST EUROPE: www.foresteurope.org.

Workshop Forest Europe: http://www.foresteurope.org/en/valuation

Forest Soil C-Sink Nordic Network: http://www.nordforsk.org/en/programs/prosjekter/forest-soil-c-sink-nordicnetwork?set_language=en_As well as: http://www.cforsoil.org

Future Forest: www.futureforests.se

Global carbon project: www.globalcarbonproject.org

Heureka: www.slu.se/heureka

InVEST, Integrated Valuation on Environmental Services and Tradeoffs:

http://www.naturalcapitalproject.org/InVEST.html

Intergovernmental Platform on Biodiversity and Ecosystem Services (IPBES):

http://www.ipbes.net/

Millennium Ecosystem Assessment (2005) Ecosystems and Human Well-Being: Synthesis http://www.unep.org/maweb/en/Index.aspx

Outdoor Recreation in Change: www.friluftsforskning.se

SNS Network on Environmental Services (CAR-ES):

http://www.nordicforestresearch.org/car-es/_and http://www.nordicforestrycares.org

Strategic Plan for Biodiversity 2011-2020 (2010), Convention on Biological Diversity: http://www.cbd.int/sp/

TEEB The Economics of Ecosystems and Biodiversity: http://www.teebweb.org/

The EU Biodiversity Strategy to 2020:

http://ec.europa.eu/environment/nature/info/pubs/docs/brochures/2020\%20Bio d\%20brochure\%20final\%20lowres.pdf

The UK National Ecosystem Assessment (UK NEA 2011) http://uknea.unep-wcmc.org/

ValueBaseSWE: http://www.beijer.kva.se/valuebase.htm 
Nordic Council of Ministers

Ved Stranden 18

DK-1061 Copenhagen K

www.norden.org

\section{Ecosystem Services in Forests}

A Nordic Workshop on "Ecosystem Services in Forests - how to assess and value them" was held in Oslo Thursday the 13th of September 2012. During the day, 13 presentations were made, and altogether 41 participants had the opportunity to discuss the way forward and to formulate issues and research fields as recommendations to the Nordic Council of Ministers. This report presents a synthesis of the presentations and provides a brief summary of issues that were raised in the discussions. The workshop addressed both current knowledge of services as well as challenges and possibilities related to assessment and valuation, and challenged participants to formulate new and important issues based on their respective fields of expertise.

TemaNord 2014:534

ISBN 978-92-893-2785-5

ISBN 978-92-893-2786-2 (EPUB)

ISSN 0908-6692
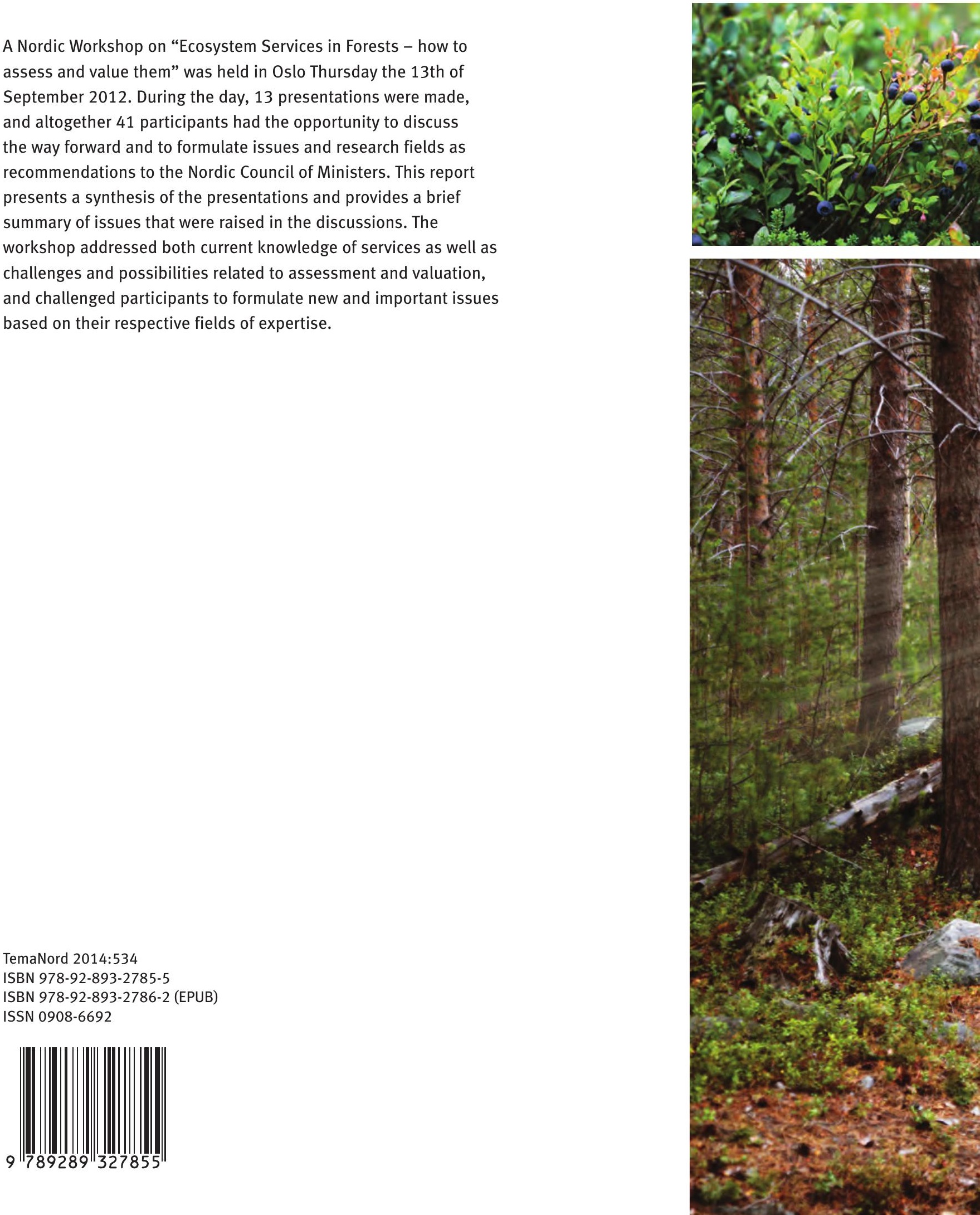